\title{
Forest vegetation diversity of the Slivenska Mountain (Eastern Stara planina, Bulgaria)
}

\author{
Alexandra Alexandrova*,1, Marius Dimitrov ${ }^{1}{ }^{(1)}$, Kiril Vassilev ${ }^{2}$ (D), \\ Desislava Sopotlieva ${ }^{2}$ (D) , Hristo Pedashenko ${ }^{2,3}$ (1) \& Alexander Tashev ${ }^{1}$ (1)
}

Key words: southeastern Bulgaria, Braun-Blanquet approach, syntaxonomy, broad-leaved forests, vegetation diversity.

Ključne besede: jugovzhodna Bolgarija, Braun-Blanquetova metoda, sintaksonomija, gozdovi listavcev, raznolikost vegetacije.

\begin{abstract}
This study deals with the diversity of forest vegetation in the Slivenska Mountain (Eastern Stara planina) and presents a contemporary classification scheme for the identified syntaxa. A total of 137 relevés were collected and analyzed using specialized software (JUICE 7.0 and PC-ORD Version 4). As a result, forest vegetation is classified into 10 associations, 3 subassociations, 4 variants and 5 communities They belong to 7 alliances, 5 orders and 3 classes: Carpino-Fagetea sylvaticae, Quercetea pubescentis and Alno glutinosae-Populetea albae. The recorded 18 distinguished vegetation groups show a relatively high diversity of forest plant communities of the study area.

Izvleček

V raziskavi smo obravnavali raznolikost gozdne vegetacije gorovja Slivenska planina (vzhodna Stara planina) in predstavlja sodobno klasifikacijsko shemo preučenih sintaksonov. Zbrali smo 137 vegetacijskih popisov in jih analizirali s specializiranimi računalniškimi programi (JUICE 7.0 in PC-ORD Version 4). Gozdno vegetacijo smo uvrstili v 10 asociacij, 3 subasociacije, 4 variante in 5 rastlinskih združb. Uvrščamo jih v 8 zvez, 6 redov in 3 razrede: Carpino-Fagetea sylvaticae, Quercetea pubescentis in Alno glutinosae-Populetea albae. Obravnavanih 18 vegetacijskih skupin predstavlja relativno veliko raznolikost gozdnih rastlinskih združb na preučevanem območju.
\end{abstract}

Received: 8. 2. 2019

Revision received: 13.2 .2020

Accepted: 20. 4. 2020

\footnotetext{
1 Faculty of Forestry, University of Forestry, 10 Kliment Ohridski Blvd., 1797 Sofia, Bulgaria. E-mail: a.v.alexandrova@abv.bg,mariusdimitrov@1tu.bg, altashev@abv.bg

2 Department of Plant and Fungal Diversity and Resources, Institute of Biodiversity and Ecosystem Research, 23 Acad. Georgi Bonchev str., 1113 Sofia, Bulgaria. E-mail: kiril5914@abv.bg, desislava.sopotlieva@iber.bas.bg, hristo_pedashenko@yahoo.com

3 Self-employed, Amsterdam, Netherlands. E-mail: hristo_pedashenko@yahoo.com
} 


\section{Introduction}

The vegetation diversity studies are especially actual topic in the context of natural habitats identification and biodiversity protection. Despite the recently increased number of phytosociological researches, following the BraunBlanquet approach, and also the existence of the general Bulgarian syntaxa scheme, the knowledge of vegetation diversity of the country is still incompleted (Tzonev et al. 2009). Inventory and actual classification of local vegetation diversity of particular areas are one of the possible ways to fill this gap. The western part of Eastern Stara planina is a suitable area for such study, due to its generally semi-natural origin of the vegetation with the presence of some relict species and plant communities (Bondev 2002). The position of this area at the edge between Euxinian and Balkan deciduous forest results to specific species composition of forest vegetation. Bondev (2002) notes that mesophytic and xero-mesophytic forest communities, dominated by Fagus sylvatica subsp. moesiaca, Carpinus betulus and Quercus petraea agg. (incl. Q. petraea subsp. petraea and Q. dalechampii) prevail in this part of Stara planina Mt. Occasionally forests of Quercus polycarpa (syn. Q. petraea subsp. iberica) and Tilia tomentosa also occur. At lower elevations, xerophytic forests are typical, presented by mixed semi-natural forests of Quercus frainetto and Q. cerris, while on more dry and sunny slopes are replaced by Carpinus orientalis forests. Communities of Syringa vulgaris, which is a Balkan sub-endemic species cover limited areas on steep and rocky slopes (Bondev 2002).

Western part of the Eastern Stara planina Mt. consists of a cluster of geografically separated mountains (e.g. Kotlenska Mt., Varbishka Mt., Slivenska Mt. and Stidovska Mt.). Being a part of this territory, the Slivenska Mt. shares the same general ecological characteristics of the potential and secondary vegetation. The significant part of previous vegetation studies of the Slivenska Mt. have been of a common descriptive character or carried out following the Dominance approach (see Apostolova \& Slavova 1997), as a part of national (e.g. Stoyanov 1941, Bondev 1991) or regional studies, for example, on the territory of Sinite kamani Nature Park (Andreev 1981, Stoeva 2004).

According to one of the first geobotanical divisions of Bulgarian vegetation made by Stoyanov (1941), the area of the Slivenska Mt. has been classified within the Eastern part of the Stara planina phytoclimatic region. The vegetation of this region is characterized by the presence of numerous Mediterranean species, as well as the appearance of some Euxinian floristic elements. Forest vegetation in this phytoclimatic region is presented by Fagus sylvatica, Carpinus betulus, Quercus cerris, Q. frainetto, mixed Querus sp. div., Fraxinus ornus and Carpinus orien- talis forests. According to the vegetation map of Bulgaria (Bondev 1991), the area of the Slivenska Mt. is covered predominantly by Fagus sylvatica subsp. moesiaca and Quercus daleschampii forests. Following the Dominance approach (Trass 1976), Stoeva (2004) found 8 formations and 46 associations presenting forest vegetation, on the territory of Sinite Kamani Nature Park.

The first research of forest vegetation of the Slivenska Mt., following the Braun-Blanquet approach, was related to the entire territory investigation of Bulgarian beech forests which included relevés from Karandila locality, which is a part of the Slivenska Mt. (Tzonev et al. 2006). Galio pseudaristati-Fagetum, Asperulo odorati-Fagetum and Luzulo luzuloidis-Fagetum sylvaticae associations were distinguished as a part of this study. Later on, Sopotlieva et al. (2016) studied vegetation of Kutelka reserve (also part of the Slivenska Mt.) and classified communities down to alliance levels, assigned forest phytocenoses into 4 alliances (Cephalanthero-Fagion, Fagion sylvaticae, Quercion petraeo-cerridis and Syringo-Carpinion), 2 orders (Fagetalia sylvaticae, Quercetalia pubescentis) and 2 classes (Querco-Fagetea, Quercetea pubescentis). The study of Sopotlieva et al. (2016) was the first one that state indentified forest vegetation syntaxa to the respective habitat types. Recently, as a part of the study of thermophytic oak forests of Bulgaria, Tzonev et al. (2019) used 34 relevés from the territory of the Slivenska Mt., which were assigned to 3 associations (Quercetum frainetto-cerridis, Genisto carinalis-Quercetum petraeae, Genisto januensisQuercetum pubescentis) and 3 alliances (Quercion confertae, Quercion petraeo-cerridis, Carpinion orientalis) of class Quercetea pubescentis.

Unfortunately, all these studies do not give a comprehensive review of the forest vegetation of the Slivenska Mt. The objective of this research was to study the diversity of forest vegetation in the Slivenska Mt. (Eastern Stara planina) and to suggest a contemporary classification scheme for the identified syntaxa.

\section{Methods}

\section{Study area}

The Slivenska Mt. is located in southeastern Bulgaria at the most western part of the Eastern Stara planina (Balkan range) (Steffanov 2002). The borders of the mountain are: on the north along the Luda Kamchia river which separates it from the Kotlenska Mt., on the south it follows the Assenovska river and the Slivensko pole plain, on the west along the Vratnik pass which devides it from the Eleno-Tvardishka Mt., and on the east Icherenski pass delimits it from the Stidovska Mt. The southeastern 


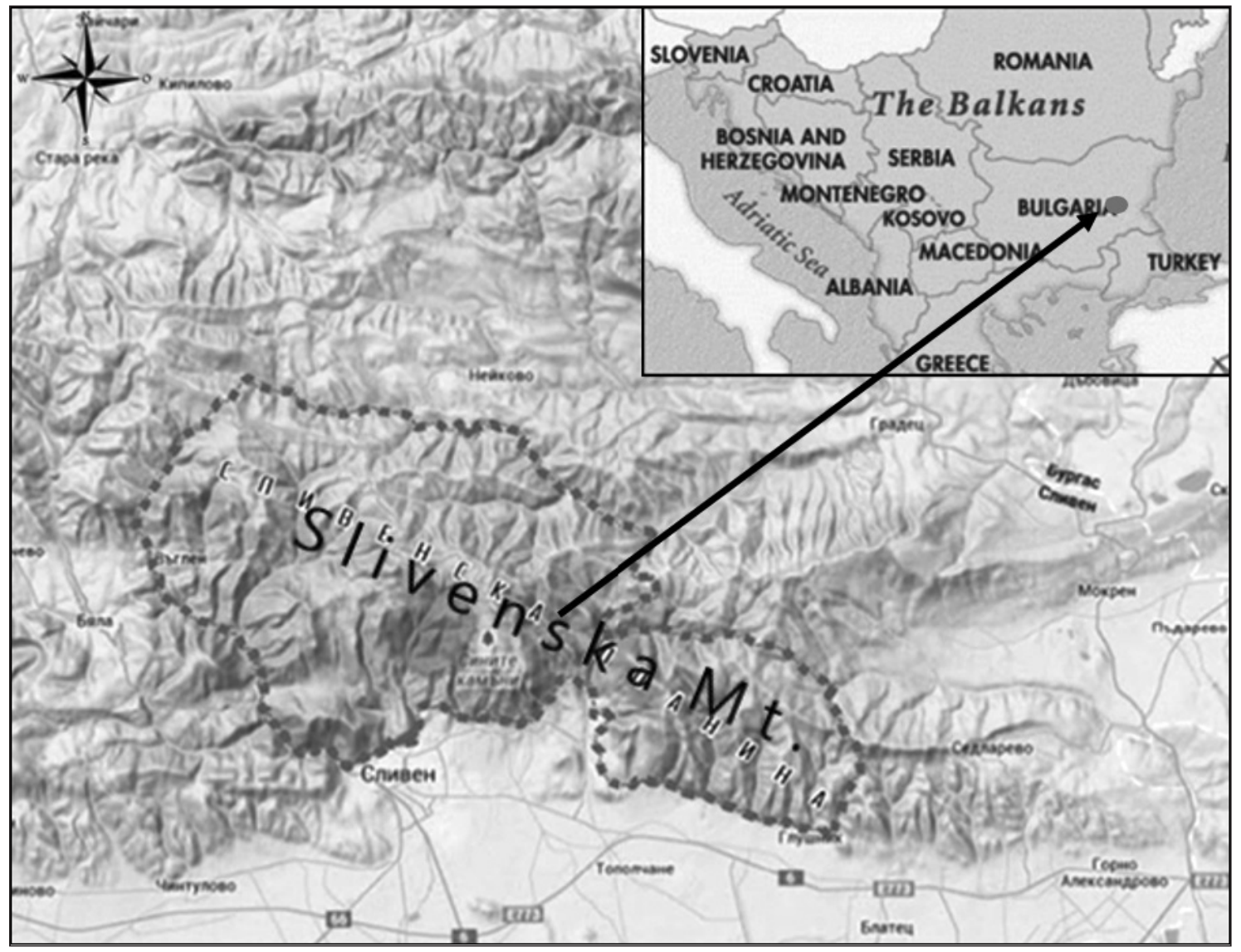

Figure 1: Slivenska Mt.'s map. Slika 1: Zemljevid Slivenske planine.

part of the Slivenska Mt. belongs to the Grebenets ridge, which borders on north and east follow the valleys of the Ovcharitsa and Marash rivers, while to the south it borders with the Slivensko pole plain (Figure 1). The total area of the Slivenska Mt. is $212.267 \mathrm{~km}^{2}$.

The physico-geographical division of the country assignes the Slivenska Mt. to the Southern low-mountainous sub-region of the Forebalkan-Eastern Balkan Mountains (Yordanova et al. 2002). The bedrocks of the study area are predominantly lower Cretaceous sandstones and marls, which pass into upper Cretaceous and Paleogene flysch formations. According to the climate division, the study area falls into the Trans-Continental climatic region and the Eastern Balkan Range climatic region (Velev 2002). The characteristic features of this climate are warm and slightly arid summer and mild winter, with small annual temperature amplitude, and two maximums (July and November) and two minimums (August and February) of annual rainfalls with an average of $600 \mathrm{~mm}$. According to the hydrological division, the study area falls in area with Mediterranean climate influence on the outflow and in the Eastern Balkan region, which is characterized by increased aquifer, poorly regulated groundwater runoff and relatively deep shallow water, which corresponds to a relatively large tide of waters (Yordanova 2002). Soil cover, at lower parts of the study area (below $500 \mathrm{~m}$ a.s.l.), falls into the Eastern Balkan province of the CarpathianDanube soil region, while the higher study area parts falls into the Balkan Mountains of the Mediterranean soil region (Ninov 2002). According to the geobotanical division of Bulgaria (Bondev 2002), the Slivenska Mt. belongs to the European Broad-leaved Forest Area, Illyrian (Balkan) Province and Kotlensko-Preslavski District.

Seven protected areas fall within the Slivenska Mt. boundaries: part of Sinite Kamani Nature Park and Kutelka Reserve; Protected sites - Lale Bair, Orlite, and Trakiiski klin; Natural monuments - Halkata and Zmeevi dupki. Three NATURA 2000 network sites overlap with the study area: BG000016 Sinite kamani and BG0000420 Grebenets (under the Habitat Directive) and BG0002058 Sinite kamani - Grebenets (under the Bird Directive). One Important Plant Area (IPA) site (BGIPA101 Sinite kamani), covering an area of $122.80 \mathrm{~km}^{2}$ (Peev et al. 2012) are also included in the territory of study area. 


\section{Vegetation data colection and processing}

The field studies were conducted during 2014-2016 vegetation seasons. Total of 137 relevés were collected from forests, following the Braun-Blanquet approach (BraunBlanquet 1964). The relevés were taken in homogeneous parts of forest stands. Size of the relevés was in the range 100-400 m² (Chytrý \& Otýpková 2003). For each relevé, complete species composition of vascular flora was recorded. Total vegetation cover, as well as the cover of tree, shrub and herbaceous layers were also recorded. The abundance of each species was estimated by its projective coverage in percentages, which are later transformed into 7-grade Braun-Blanquet scale (Braun-Blanquet 1964). If one species occurs in several layers in a single relevé it was recorded for each of them. The data for topographic and ecological peculiarities were collected in the field (e.g. elevation, aspect, slope), whereas basic soil data (e.g. soil type and some soil characteristics as a soil reaction, soil depth and humidity) was exctracted from the Forest Management Plan of State Forestry Unit Sliven (2012) and Forest Management Plan of State Forestry Unit Kotel (2014). All relevés were digitized in Excel format and stored in the Balkan Vegetation database (Vassilev et al. 2016) using TURBOVEG format (Hennekens \& Schaminée 2001).

The taxonomic status of all plants is standardized according to the Euro + Med Plant Database (http://www. emplantbase.org/home.html). Taxa identified with different taxonomic precision were merged to species sensu lato or species aggregates.

All relevés were exported in JUICE 7.0 software (Tichý 2002). Agglomerative method (PC-ORD, McCune \& Mefford 1999) was used for numerical analysis. Square root transformation of species cover and a minimum number of 2 relevés by cluster were used. Relative Sorensen was used as distance measure and similarity was calculated by Flexible beta $(\beta=-0.25)$. The phi coefficient of association was used as a measure of fidelity (Sokal \& Rohlf 1995, Chytrý et al. 2002), and all clusters were standardized to equal size (Chytrý et al. 2006). Only the statistically significant phi-coefficient values evaluated by Fisher's exact test $(\mathrm{P}<0.05)$ were considered. For each resulted group the diagnostic, constant and dominant species were defined by „Analysis of constancy columns in synoptic table" function in JUICE software. The threshold value for a species to be considered as diagnostic was set up at phi-coefficient $\geq 0.3$. The list of constant species includes species with presence at least $40 \%$ of relevés in a cluster, whereas species with coverage above $20 \%$ were considered as dominants. Finally, in the "Results and discussion" section, the value of each species phi-coefficient per group was presented in parentheses multiplied by 100 . Respectevely, values in parentheses for a constant species signify their percentages constancy per group, while for the dominant species in the parentheses are shown the percentages ratio of relevés of the target group where the dominant species cover was above the defined threshold. The final synoptic table presented both species percentage frequency and fidelity (Appendix 1).

The syntaxa nomenclature to alliance level follows the concept of Mucina et al. (2016). For suballiances of Moesian beech forests we accept the scheme of Willner et al. (2017). The classification of recorded vegetation units is determined after a comparative analysis of the diagnostic, constant and dominant species groups with those indicated in literature (Kojić et al. 1998, Roleček 2005, Tzonev et al. 2006, 2009, 2019, Čarni et al. 2009, 2016a, 2016b, Borhidi et al. 2012, Chytrý 2013, Biondi et al. 2014, Coldea et al. 2015, Douda et al. 2016, Willner et al. 2017 , etc.). Some of phytocoenoses are not referred to any association and are assigned as "community types" because of their local occurrence or limited data of their presence in other regions of Bulgaria.

\section{Results and discussion}

As a result of analysis, on the territory of the Slivenska Mt., 18 vegetation units of forest vegetation are identified (Figure 2, Appendix 1). They are classified into 3 classes, 5 orders, 7 alliances, 10 associations, 3 subassociations, 4 variants and 5 communities. The mesophytic beech and xero-mesophytic hornbeam forest communities of class Carpino-Fagetea sylvaticae occupy left and middle parts of dendogram (Figure 2, groups 1-7 and 11-12). On the opposite, on the right part of dendrogram there are the xerophytic oak woodlands of Quercetea pubescentis class dominated by Quercus cerris, Q. frainetto, Q. petraea agg. and Carpinus orientalis (Figure 2, groups 9-10 and 13-18). In the center, group 8 belongs to the riparian forest vegetation of class Alno glutinosae-Populetea albae (Figure 2, group 8).

Syntaxonomical scheme of recorded plant communities: Class Carpino-Fagetea sylvaticae Jakucs ex Passarge 1968

Order Fagetalia sylvaticae Pawłowski 1928

Alliance Fagion sylvaticae Luquet 1926

Association Aremonio agrimonoidis-Fagetum sylvaticae Boșcaiu in Resmeriță 1972

Subassociation violetosum reichenbachianae Tzonev et al. 2006

Association Galio pseudaristati-Fagetum sylvaticae

Tzonev et al. 2006 
Association Carpino-Fagetum Paucă 1941

Subassociation cephalanteriosum Coldea 1975

Association Galio odorati-Fagetum sylvaticae Sougnez et Thill 1959

Community type Fagus sylvatica and Cardamine bulbifera

Order Luzulo-Fagetalia sylvaticae Scamoni et Passarge 1959

Alliance Luzulo-Fagion sylvaticae Lohmeyer et Tx. in Tx. 1954

Association Luzulo luzuloidis-Fagetum sylvaticae

Meusel 1937

Order Carpinetalia betuli P. Fukarek 1968

Alliance Erythronio-Carpinion (Horvat 1958) Marin-

ček in Wallnöfer et al. 1993

Suballiance Aceri tatarici-Carpinenion Košir et al. 2013

Association Lathyro aurei-Tilietum tomentosae nom. prov.

Community type Carpinus betulus and Stachys sylvatica

Community type Carpinus betulus and Smyrnium perfoliatum

Class Alno glutinosae-Populetea albae P. Fukarek et Fabijanić 1968

Order Alno-Fraxinetalia excelsioris Passarge 1968

Alliance Alnion incanae Pawłowski et al. 1928

Community type Alnus glutinosa and Aegopodium

podagraria
Class Quercetea pubescentis Doing-Kraft ex Scamoni et Passarge 1959

Order Quercetalia pubescenti-petraeae Klika 1933

Alliance Quercion confertae Horvat 1958

Association Quercetum frainetto-cerris (Rudski 1949)

Trinajstić et al. 1996

Subassociation typicum

Variant Quercus petraea

Alliance Carpinion orientalis Horvat 1958

Association Genisto januensis-Quercetum pubescentis (Jackus 1961) Tzonev et al. 2019

Association Arabio turritae-Carpinetum orientalis

Tzonev 2013

Community type Quercus petraea and Polygonatum latifolium

Alliance Quercion petraeo-cerridis Lakušić et B. Jovanović in B. Jovanović et al. ex Čarni et Mucina 2015

Association Genisto carinalis-Quercetum petraeae Bergmeier in Bergmeier et Dimopoulos 2008

Variant typicum

Variant Verbascum humile

Variant Festuca heterophylla

Cluster Analysis Dendrogram

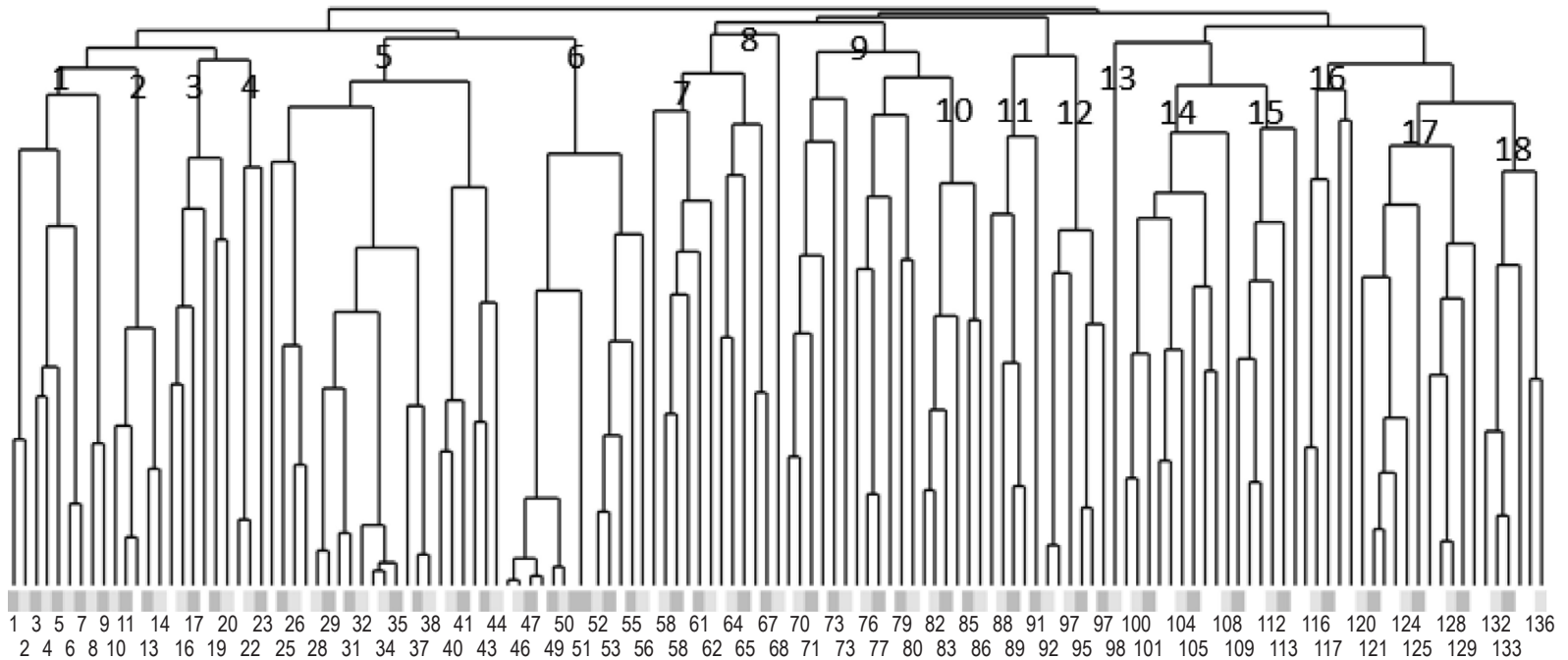

Figure 2: Classification dendrogram of forest vegetation on Slivenska Mt. (The identified forest vegetation groups' number was showen on respective dendrogram separation, while the numbers on the botton of dendrogram corresponded to relevé number).

Slika 2: Dendrogram klasifikacije gozdne vegetacije Slivenske planine (številka vegetacijske skupine je prikazana na posamezni členitvi, številke na dnu dendrograma pa predstavljajo številke vegetacijskih popisov) 
The presentation of recorded plant communities follows the suggested syntaxonomical scheme.

Group 1. Association Aremonio agrimonoidis-Fagetum sylvaticae Boşcaiu in Resmeriță 1972 subass. violetosum reichenbachianae Tzonev et al. 2006 (Figure 2, relevés 1-9; Appendix 1, gr. 1)

Diagnostic species: Galium odoratum (47.7), Lathyrus venetus (40.7), Viola reichenbachiana agg. (34.9).

Constant species: Fagus sylvatica (100), Melica uniflora (78), Lactuca muralis (78), Prunus avium (67), Euphorbia amygdaloides (67), Poa nemoralis (56), Schedonorus giganteus (44), Quercus cerris (44), Potentilla micrantha (44), Mercurialis perennis (44), Acer platanoides (44).

Dominant species: Fagussylvatica (89), Tilia tomentosa (11).

These forests are developed on steep slopes $\left(20-35^{\circ}\right)$, predominantly on northern and eastern aspect and elevation between $750-1000 \mathrm{~m}$ a.s.l. in the Slivenska Mt. The Cambisols soils, moderately-deep with a neutral reaction prevail. The tree layer is dominated by Fagus sylvatica, but Prunus avium, Quercus cerris, Q. frainetto, Tilia tomentosa, Carpinus betulus, Acer pseudoplatanus also occur. In these forests, shrub layer is almost absent, but in some places undergrowth formed by juvenile plants of the species forming tree layer occurs. The herbaceous layer has a cover between 20 and $60 \%$ built by nemoral species as Melica uniflora, Poa nemoralis, Galium odoratum, Viola reichenbachiana agg. These forests have seed or copiced origin.

The species composition of the studied phytocoenoses are very similar to the Galio odorati-Fagetum sylvaticae association, but includes a numerous thermophilic species, such as Quercus cerris, Q. frainetto, Sorbus torminalis, Campanula rapunculoides, Primula veris, Lathyrus laxiflorus, Hedera helix, Potentilla micrantha. According to Willner et al. (2017) scheme, such communities could be assigned to Doronico orientalis-Fagenion moesiacae suballiance - thermo-basophilic beech forests of the Balkan Peninsula.

This vegetation type has been described by Tzonev et al. (2006), as a geographically distinct subassociation of the Aremonio agrimonoidis-Fagetum sylvaticae association, originally described in Romania (Coldea 1991).

Group 2. Association Galio pseudaristati-Fagetum sylvaticae Tzonev et al. 2006 (Figure 2, relevés 10-14; Appendix 1, gr. 2)

Diagnostic species: Cephalanthera damasonium (68.9), Cotoneaster integerrimus (62.2), Cephalanthera rubra (60.2), Sorbus aucuparia (55.5), Lilium martagon (48.0), Ajuga reptans (46.6), Seseli rigidum (43.7), Orthilia secunda (43.7), Milium effusum (43.7), Juniperus communis (43.7), Epipactis microphylla (43.7),
E. helleborine (43.7), Primula veris (41.5), Mercurialis perennis (36.9), Viola reichenbachiana agg. (36.2), Sorbus torminalis (35.6), Physospermum cornubiense (35.1), Lathyrus vernus (33.8), Acer pseudoplatanus (32.1), Campanula rapunculoides (30.4), Euphorbia amygdaloides (30.3).

Constant species: Fagus sylvatica (100), Lathyrus laxiflorus (80), Acer campestre (80), Poa nemoralis (60), Lactuca muralis (60), Cornus mas (60).

Dominant species: Fagus sylvatica (100).

The association is represented by 5 relevés. Its stands are found at the range of $850-1000 \mathrm{~m}$ a.s.l., on moderately-steep slopes $\left(15-30^{\circ}\right)$ and aspects with western component on moderately-deep Cambisols or Rendzinas soils and calcareous bedrock. Fagus sylvatica dominates in the tree layer. Due to the consequence of tree layer shading effect, a shrub layer is missing and herbaceous layer is poorly developed. Occurence of some orchid species (Cephalanthera damasonium, C. rubra, Epipactis microphylla, E. helleborine) is common. These communities have a well-expressed thermophilic character and mosaic distribution, strongly influenced by the surrounding oak forests. Most of them are located in the Karandila locality and eastern of it. They are mainly high forests, partly influenced by human activity, as a result of their distribution near tourist paths.

For this association the presence of species characteristic for Quercus frainetto forests (such as Euphorbia amygdaloides, Lathyrus vernus, Physospermum cornubiense, Sorbus torminalis) is typical (Tzonev et al. 2006). Similar vegetation - Tilio tomentosae-Fagetum sylvaticae Tzonev et al. 2006 association has been described from northeastern Bulgaria (Tzonev et al. 2006). The floristic composition of group 2 shows similarities to it, but many of the diagnostic species are missing. Tzonev et al. (2006) refer both associations (Galio pseudaristati-Fagetum sylvaticae and Tilio tomentosae-Fagetum sylvaticae) to the thermophilic beech forests in the country and classified them to alliance Cephalanthero-Fagion sylvaticae Tüxen 1955. Sopotlieva et al. (2016) also assigned basiphilous beech forest of Kutelka Reserve to the alliance CephalantheroFagion sylvaticae. According to the recent syntaxonomical scheme of European vegetation (Mucina et al. 2016), this alliance is considered as synonymous of alliance Fagion sylvaticae Luquet 1926.

Group 3. Association Carpino-Fagetum Paucă 1941 subass. cephalanteriosum Coldea 1975 (Figure 2, relevés 15-20; Appendix 1, gr. 3)

Diagnostic species: Viola reichenbachiana agg. (42.6), Geum urbanum (41.6), Symphytum tuberosum (39.9), Ranunculus polyanthemos (39.9), Hordelymus europaeus 
(39.9), Chaerophyllum byzantinum (39.9), Geranium robertianum (38.6), Sambucus nigra (36.1), Tanacetum corymbosum (33.4), Myosotis sylvatica (33.0), Rubus caesius (31.8).

Constant species: Fagus sylvatica (100), Potentilla micrantha (83), Poa nemoralis (83), Lactuca muralis (83), Carpinus betulus (83), Lathyrus laxiflorus (67), Crataegus monogyna (67), Viola hirta (50), Quercus cerris (50), Physospermum cornubiense (50), Euphorbia amygdaloides (50), Brachypodium sylvaticum (50), Aremonia agrimonoides (50), Acer campestre (50).

Dominant species: Fagus sylvatica (83), Carpinus betulus (67), Prunus avium (17).

The stands of this forest type have a mosaic spread, mainly around gullies and in wetter places. They are found on moderately-steep slopes $\left(15-35^{\circ}\right)$, with predominantly eastern aspect and elevation between 600-900 m a.s.l., on moderately-deep and fresh Cambisols. Tree layer is dominated by Fagus sylvatica or Carpinus betulus. Other tree species are Prunus avium, Quercus cerris and Acer pseudoplatanus. Shrub layer is not well-developed and is formed by Corylus avellana, Carpinus orientalis and Crataegus monogyna. Herbaceous layer cover is low, between 1 and 40\%. Most abundant species are Mycelis muralis, Galium odoratum, Viola reichenbachiana agg. Species composition includes also some characteristic species for oak forests such as Viola hirta, Geum urbanum, Geranium robertianum, Lathyrus laxiflorus, Campanula rapunculoides and Circaea lutetiana. These woodlands have seed or coppiced origin.

Floristically and ecologically, this vegetation shares some common species with Carpino-Fagetum Paucă 1941 subass. cephalanteriosum Coldea 1975, such as Carpinus betulus, Acer campestre, Qurcus cerris, Prunus avium, Corylus avellana, Crataegus monogyna, Poa nemoralis, Brachypodium sylvaticum, Anemone nemorosa, Cephalanthera longifolia, C. damasonium, Epipactis helleborine, Dryopteris filixmas, Athyrium filix-femina, etc. (Burescu \& Lacatos 2010, Coldea et al. 2015). Most of them are distinguished as diagnostic in our dataset (see synoptic table in Appendix 1). The association has already been reported for Bulgaria by Soó (1964) from Lyulin Mts and Dimitrov et al. (2004) from Vitosha Mts. These forest communities are transitional between thermophilic beech and hornbeam forests.

\section{Group 4. Association Galio odorati-Fagetum sylvaticae} Sougnez et Thill 1959 (Figure 2, relevés 21-23; Appendix 1, gr. 4)

Diagnostic species: Epilobium montanum (65.3), Sambucus nigra (59.1), Rubus idaeus (56.6), Lunaria rediviva (56.6), Aconitum lycoctonum s.l. (56.6), Dryopteris filix-mas (50.1), Geranium robertianum (48.7), Chaerophyllum aureum (48.2), Alliaria petiolata (46.2), Acer pseudoplatanus (43.4), Stachys sylvatica (42.5), Sanicula europaea (39.0), Mercurialis perennis (36.9).

Constant species: Fagus sylvatica (100), Lactuca muralis (67), Galium odoratum (67), Euphorbia amygdaloides (67), Cardamine bulbifera (67).

Dominant species: Fagus sylvatica (100), Mercurialis perennis (33), Acer pseudoplatanus (33).

Stands of this community occure on moderately-deep Cambisols, rich with nutrients, fresh, with a neutral reaction on higher elevations than previous types - between 1050-1100 m a.s.l., on steep slopes with northern aspect. Tree layer is dominated by Fagus sylvatica and in one relevé by Acer pseudoplatanus. Shrub layer is poorly developed, formed by the same species as tree layer together with Sambucus nigra and Crataegus monogyna. Herbaceous layer cover is $30-60 \%$. These forests have diverse origin, but high forests predominate. They are strongly influenced by human activity, which is also emphasized by the presence of nitrophytes in their floristic composition - Urtica dioica and Alliaria petiolata.

This association was firstly reported for Bulgaria by Tzonev et al. (2006) distributed in mountain regions.

Group 6. Community type Fagus sylvatica and Cardamine bulbifera (Figure 2, relevés 45-57; Appendix 1, gr. 6)

\section{Diagnostic species: -}

Constant species: Fagus sylvatica (100).

Dominant species: Fagus sylvatica (100).

This group incorporates monodominant communities of Fagus sylvatica with very poor species composition, without defined diagnostic species when compared to other studied managed forest types. Stands of this community occur on moderately-deep Cambisols on northern and eastern steep slopes $\left(20-30^{\circ}\right)$, and elevations between 720 and $1030 \mathrm{~m}$ a.s.l. Species composition is transitional including characteristic species for alliance Luzulo-Fagion sylvaticae (species such as Luzula luzuloides, Poa nemoralis), alliance Fagion sylvaticae (such as Cardamine bulbifera, Galium odoratum, Mercurialis perennis, Neotia nidus-avis, Viola reichenbachiana agg.) and oak forests (such as Quercus cerris and Lathyrus laxiflorus). The origin varies among different forest patches, but high forests predominate.

Group 5. Association Luzulo luzuloidis-Fagetum sylvaticae Meusel 1937 (Figure 2, relevés 24-44; Appendix 1, gr. 5)

Diagnostic species: Hieracium racemosum (36.9).

Constant species: Fagus sylvatica (100), Carpinus betulus (86), Luzula luzuloides (71), Lactuca muralis (67), Poa nemoralis (62). 
Dominant species: Fagus sylvatica (100), Carpinus betulus (10), Carpinus orientalis (5).

The association includes acidophilous beech high forests, which are widespread on the territory of the country (Tzonev et al. 2006). Stands of this community occur on steep slopes $\left(20-40^{\circ}\right)$, with predominantly northern and western aspect on elevation between 550 and $1100 \mathrm{~m}$ a.s.l. The majority of phytocoenoses are located mainly in the higher parts of the study area, especially around Balgarka peak, skeletal and shallow acidic Cambisols with rocky outcrops. Tree layer is dominated by Fagus sylvatica, whereas Carpinus betulus and Quercus petraea agg. are subdominants. Shrub layer usually is not developed or with low cover, formed by juvenile plants of the species appearing in the tree layer. Herbaceous layer is usually well-developed (ranges between 5 and $70 \%$ cover), but with poor species composition, including species such as Luzula luzuloides, Poa nemoralis, Moehringia trinervia, Mycelis muralis, Hieracium murrorum, Veronica officinalis, Lamium galeobdolon. The most recent studies of such Balkan beech forests usually accepted an affiliation them to well known central European alliance Luzulo-Fagion (Tzonev et al. 2006, Čarni 2016a, Willner et al. 2017). According to Willner et al. (2017), this association refers to the sub-alliance Luzulo luzuloidis-Fagenion II (LuzuloFagenion moesiacae) - acidophilous beech forests in the northeastern part of the Balkan Peninsula.

Group 7. Community type Carpinus betulus and Stachys sylvatica (Figure 2, relevés 58-63; Appendix 1, gr. 7) Diagnostic species: Corylus avellana (46.7), Stachys sylvatica (42.5), Sanicula europaea (39.0), Clematis vitalba (37.5), Pulmonaria officinalis (37.3), Cornus mas (35.8), Brachypodium sylvaticum (32.4), Rosa canina (32.2), Cruciata laevipes (31.2), Geum urbanum (31.0), Arctium lappa (30.1).

Constant species: Carpinus betulus (100), Lactuca muralis (83), Euphorbia amygdaloides (83), Crataegus monogyna (83), Acer campestre (83), Prunus avium (67), Primula veris (67), Potentilla micrantha (67), Poa nemoralis (67), Geranium robertianum (67), Viola hirta (50), Schedonorus giganteus (50), Quercus petraea agg. (50), Aremonia agrimonoides (50).

Dominant species: Carpinus betulus (100), Quercus petraea agg. (33), Corylus avellana (17), Acer campestre (17). This vegetation type is distributed from 500 to $800 \mathrm{~m}$ a.s.l., along ditches formed into beech or oak forests on fresh to moist soils, on moderately-steep (up to $20^{\circ}$ ) slopes with northern and eastern aspect. Tree layer is formed by Carpinus betulus, which is a dominant species, and other single trees as Fagus sylvatica, Quercus petraea agg., Salix alba, Prunus avium. Shrub layer is poorly developed, formed by Cornus mas, Corylus avellana and Crataegus monogyna. Herbaceous layer is well developed including some mesophylic species (such as Aegopodium podagraria, Arctium lappa, Stachys sylvatica) and other common from the adjacent phytocenoses (e.g. Aremonia agrimonoides, Brachypodium sylvaticum, Dactylis glomerata, Euphorbia amygdaloides, Schedonorus giganteus, Galium odoratum, Melica uniflora, Mercurialis perennis, Mycelis muralis, Poa nemoralis, Potentilla micrantha, Primula veris, Pulmonaria officinalis, Sanicula europaea). The recorded large number of nitrophytes (Alliaria petiolata, Arctium lappa, Galium aparine, Geranium robertianum, Geum urbanum, Prunella vulgaris) shows a strong anthropogenic impact. In the dendrogram, this vegetation is placed close to communities of Alnus glutinosa and Aegopodium podagraria, due to the presence of nitrophilous riparian forests species.

Group 11. Community type Carpinus betulus and Smyrnium perfoliatum (Figure 2, relevés 88-92; Appendix 1, gr 11)

Diagnostic species: Smyrnium perfoliatum (43.7).

Constant species: Quercus petraea agg. (100), Carpinus betulus (100), Poa nemoralis (80), Melica uniflora (60), Lactuca muralis (60), Fagus sylvatica (60).

Dominant species: Carpinus betulus (100), Quercus petraea agg. (20), Melica uniflora (20), Glechoma hederacea (20).

This vegetation type occures on steep $\left(25-40^{\circ}\right)$ sunny slopes with western and southern aspect, and elevation between 600 and $950 \mathrm{~m}$ a.s.l. Tree layer is dominated by Carpinus betulus, but Quercus petraea agg., Q. frainetto, Fagus sylvatica, Prunus avium are also abundant species. Shrub layer is underdeveloped, with poor species composition. Herbaceous layer is with low cover of $15-20 \%$. Constant species within it are Poa nemoralis, Dactylis glomerata, Euphorbia amygdaloides, Geum urbanum, Geranium robertianum, Melica uniflora, Lamium galeobdolon, Mycelis muralis, Potentilla micrantha, Galium odoratum.

This community type has a mosaic distribution in the study area, together with communities of Fagus sylvatica and Quercus petraea agg., which is emphasized by the presence of typical species for both groups. The recorded large numbers of nitrophytes (e.g. Alliaria petiolata, Arctium lappa, Galium aparine, Geranium robertianum, Geum urbanum, Pteridium aquilinum) show strong anthropogenic pressure in these forests.

The phytocoenoses of hornbeam in Bulgaria up to now are related to associations Galio sylvatici-Carpinetum betuli Oberd. 1957 (Tzonev et al. 2009) and Carpinetum betuli Dinic 1977 s.l. with three variants of Aegopodium podagraria, Tanacetum corymbosum and Torilis japonica (Apostolova-Stoyanova et al. 2005). Generally, Carpinus 
betulus dominated vegetation is still poorly studied on the country territory and the respective syntaxa are unclear, which determine our classification decision of its phytocoenoses from the territory of the Slivenska Mt. on a community type level.

Group 12. Association Lathyro aurei-Tilietum tomentosae nom. prov. (Figure 2, relevés 93-98; Appendix 1, gr. 12)

Diagnostic species: Lathyrus aureus (82.3), Tilia tomentosa (55.8), Campanula grossekii (48.9), Glechoma hederacea (45.7), Lamium galeobdolon (45.5), Hedera helix (45.2), Asplenium adiantum-nigrum (39.9).

Constant species: Fagus sylvatica (100), Carpinus betulus (100), Mercurialis perennis (83), Quercus petraea agg. (67), Poa nemoralis (67), Physospermum cornubiense (67), Melica uniflora (67), Fraxinus ornus (67), Sorbus torminalis (50), Potentilla micrantha (50), Lathyrus niger (50), Lactuca muralis (50), Corylus avellana (50), Cornus mas (50), Arabis turrita (50), Acer campestre (50).

Dominant species: Tilia tomentosa (50), Carpinus betulus (50), Quercus petraea agg. (17), Fagus sylvatica (17).

These forest phytocoenoses occur in the central part of the study area on moderately-deep Chromic Luvisols or Rendzinas, on steep slopes $\left(35-40^{\circ}\right)$, and elevation between 500 and $650 \mathrm{~m}$ a.s.l. Tree layer is formed by codominance of Tilia tomentosa, Carpinus betulus, Fagus sylvatica, Quercus petraea agg., Acer campestre and Sorbus torminalis. Shrub layer is poorly developed ( $10 \%$ of cover), formed by same species as tree layer. Herbaceous layer cover is 20 30\%, formed by Aremonia agrimonoides, Brachypodium sylvaticum, Glechoma hederacea, Hedera helix, Lamium galeobdolon, Lathyrus aureus, Lathyrus niger, Melica uniflora, Mercurialis perennis, Mycelis muralis, Physospermum cornubiense, Poa nemoralis, Potentilla micrantha. Species composition includes some beech forest species (such as Aremonia agrimonoides, Cardamine bulbifera, Fagus sylvatica, Lamium galeobdolon, Lathyrus aureus, Melica uniflora, Mercurialis perennis, Mycelis muralis, Sanicula europaea) and oak forest species (such as Campanula persicifolia, Fraxinus ornus, Lathyrus niger, Sorbus torminalis). Such species composition is also result of the mosaic distribution of this vegetation type among beech and oak forests. These are well-preserved high forests. We assumed that the described communities are part of a more widespread association in Bulgaria. At this stage we offer a provisional name.

Group 8. Community type Alnus glutinosa and Aegopodium podagraria (Figure 2, relevés 64-69; Appendix 1, gr. 8)

Diagnostic species: Alnus glutinosa (90.8), Salix alba (71.6), Urtica dioica (65.8), Aegopodium podagraria
(64.7), Circaea luteciana (57.2), Stachys germanica (56.6), Scrophularia umbrosa (56.6), Persicaria hydropiper (56.6), Lysimachia nummularia (56.6), Torilis japonica (55.6), Prunella vulgaris (50.2), Trifolium pratense (50.0), Arctium lappa (48.1), Heracleum sphondylium s.l. (44.3), Verbena officinalis (39.9), Ulmus minor (39.9), Tripleurospermum inodorum (39.9), Trifolium campestre (39.9), Taraxacum sect. Taraxacum (39.9), Tanacetum vulgare (39.9), Stellaria nemorum (39.9), Potentilla argentea (39.9), Polypodium vulgare (39.9), Plantago lanceolata (39.9), Petasites hybridus (39.9), Mentha longifolia (39.9), Mentha aquatica (39.9), Melissa officinalis (39.9), Malva sylvestris (39.9), Juncus effusus (39.9), Hordeum bulbosum (39.9), Equisetum arvense (39.9), Cirsium arvense (39.9), Chondrilla juncea (39.9), Bromopsis inermis (39.9), Agrimonia eupatoria (39.9), Fragaria vesca (37.9), Corylus avellana (35.4), Brachypodium sylvaticum (32.4), Geum urbanum (31.0).

Constant species: Carpinus betulus (83), Lactuca muralis (67), Dactylis glomerata (67), Crataegus monogyna (67), Sambucus nigra (50), Rosa canina (50), Poa nemoralis (50), Geranium robertianum (50), Fagus sylvatica (50), Campanula rapunculoides (50), Acerpseudoplatanus (50). Dominant species: Alnus glutinosa (83), Salix alba (33), Corylus avellana (17), Carpinus betulus (17), Brachypodium sylvaticum (17).

Alnus glutinosa dominated communities are distributed on limited area along river banks of the Luda Kamchia and the Sotirska rivers between 270 and $550 \mathrm{~m}$ a.s.l., on moderately-deep alluvial soils. The forest origin is seed. Carpinus betulus and Salix alba individuals or groups partcipate in the tree layer together with Alnus glutinosa. These communities are very similary to association Stellario nemorum-Alnetum glutinosae Lohmeyer 1957, but they are drier version with more mesophytes, even xeromesophytes (such as Stachys germanica, Chondrilla juncea, Potentilla argentea, etc). For now, we refrain from referring to this association.

Groups 9-10. Association Quercetum frainetto-cerris (Rudski 1949) Trinajstić et al. 1996 (Figure 2, relevés 70-87; Appendix 1, gr. 9-10)

Diagnostic species: Lychnis coronaria (45.9), Lapsana communis (45.7), Clinopodium vulgare (39.3), Veronica chamaedrys (37.1), Quercus cerris (37.1), Hypericum perforatum (32.6), Thymus pulegioides (32.3), Paeonia peregrina (32.3), Dianthus giganteus (32.3), Agrostis capillaris (32.3).

Constant species: Poa nemoralis (100), Carpinus betulus (89), Potentilla micrantha (83), Euphorbia amygdaloides (78), Crataegus monogyna (78), Lathyrus laxiflorus (72), 
Melica uniflora (67), Lactuca muralis (67), Cornus mas (67), Brachypodium sylvaticum (67), Sorbus torminalis (61), Primula veris (61), Acer campestre (61), Rosa canina (56), Physospermum cornubiense (56), Dactylis glomerata (56), Prunus avium (44).

Dominant species: Quercus cerris (61), Quercus petraea agg. (28), Carpinus betulus (22), Poa nemoralis (11), Melica uniflora (11), Quercus frainetto (6), Corylus colurna (6).

This association is presented by 18 relevés. Its stands occur between 550 and $1000 \mathrm{~m}$ a.s.l., on medium rich of nutrients skeletal Cambisols and Chromic Luvisols, on slightly to moderately-steep slopes $\left(5\right.$ to $\left.35^{\circ}\right)$ with varying aspects. The cover of tree layer is between 50 and $85 \%$ with dominance of Quercus cerris and codominance of Q. petraea agg., Q. frainetto, Carpinus orientalis, Sorbus torminalis. The coppiced origin of forests prevails in these phytocoenoses. Shrub layer is undeveloped in some stands due to the closed canopy of the tree layer. On other places shrub layer is formed by Crataegus monogyna, Cornus mas, Rosa canina, Fraxinus ornus, Carpinus orientalis, Prunus spinosa. Herbaceous layer is well-developed and is species rich. Species wih higher abundance are Brachypodium sylvaticum, Poa nemoralis, Potentilla micrantha, Euphorbia amygdaloides, Clinopodium vulgaris, Lathyrus laxiflorus, Veronica chamaedrys, Hypericum perforatum, Dactylis glomerata, Mycelis muralis.

Horvat et al. (1974) reviewed diversity and distribution of an association Quercetum frainetto-cerridis (Rudski 1949) Trinajstić et al. 1996 in the Balkans as zonal plant communities in lower mountain belt (below $1200 \mathrm{~m}$ a.s.l.), on steep slopes, deep soils and silicate bedrock. It was recently mentioned for the Galicica Mountains in Macedonia (Matevski et al. 2011) and for Romania (Coldea et al. 2015). In Serbia, association is represented by 4 subassociations (Kojić et al. 1998).

Comparison of the studied communities' species composition with indicated in the literature association diagnostic, constant and dominant species reveals a great degree of similarity. The environmental conditions are also similar, which supports our decision to classify these forest communities from the Slivenska Mt. to the association Quercetum frainetto-cerridis (Rudski 1949) Trinajstić et al. 1996. Tzonev et al. (2019) also pointed out the association for Bulgaria and in particular for the Eastern Stara planina.

Group 9. Subassociastion typicum (Figure 2, relevés 70-81; Appendix 1, gr. 9)

Diagnostic species: Lychnis coronaria (56.6), Quercus cerris (46.8), Thymus pulegioides (39.9), Dianthus giganteus (39.9), Agrostis capillaris (39.9), Veronica offici- nalis (39.7), Brachypodium sylvaticum (37.1), Lapsana communis (34.8), Rosa canina (32.2), Corylus colurna (30.5).

Constant species: Poa nemoralis (100), Potentilla micrantha (83), Carpinus betulus (83), Lactuca muralis (75), Euphorbia amygdaloides (75), Crataegus monogyna (75), Sorbus torminalis (67), Primula veris (67), Prunus avium (58), Melica uniflora (58), Lathyrus laxiflorus (58), Dactylis glomerata (58), Cornus mas (58), Clinopodium vulgaris (58), Veronica chamaedrys (50), Mercurialis perennis (50), Acer campestre (50), Quercus frainetto (42), Hypericum perforatum (42), Fagus sylvatica (42).

Dominant species: Quercus cerris (83), Poa nemoralis (17), Carpinus betulus (17), Quercus frainetto (8), Melica uniflora (8), Corylus colurna (8).

Communities of typical subassociation of Quercetum frainetto-cerridis occur on the same environmental condition as described above for the association communities. The vertical structure is presented by three layers. Tree layer is dominated by Quercus cerris, with Quercus frainetto and Carpinus betulus as subdominants. In only one relevé the dominant species is Corylus colurna, while in another one-Carpinus betulus. Shrub layer is formed by same tree species as well as Crataegus monogyna, Cornus mas, Rosa canina. In herbaceous layer species with higher anundance are Poa nemoralis, Melica uniflora, Mercurialis perennis, Ajuga reptans, Potentilla micrantha, Lathyrus laxiflorus, Geum urbanum.

Group 10. Variant Quercus petraea (Figure 2, relevés 82-87; Appendix 1, gr. 10)

Diagnostic species: Lysimachia punctata (39.9), Digitalis viridiflora (39.9), Cruciata pedemontana (39.9), Lathyrus laxiflorus (35.3), Physospermum cornubiense (35.1), Lapsana communis (34.8), Clinopodium menthifolium s.l. (34.0), Clinopodium vulgare (32.9).

Constant species: Quercus petraea agg. (100), Poa nemoralis (100), Carpinus betulus (100), Potentilla micrantha (83), Melica uniflora (83), Euphorbia amygdaloides (83), Crataegus monogyna (83), Cornus mas (83), Acer campestre (83), Campanula rapunculoides (67), Veronica chamaedrys (50), Tilia tomentosa (50), Sorbus torminalis (50), Primula veris (50), Luzula luzuloides (50), Lathyrus niger (50), Lactuca muralis (50), Fraxinus ornus (50), Dactylis glomerata (50), Cruciata glabra (50), Arabis turrita (50).

Dominant species: Quercus petraea agg. (83), Carpinus betulus (33), Quercus cerris (17), Melica uniflora (17).

This variant of the Quercetum frainetto-cerris association includes oak forests located at elevations between 600 and $950 \mathrm{~m}$ a.s.l., on areas with higher soil moisture, aspect mainly with eastern and western components, on 
moderately-steep $\left(15-35^{\circ}\right)$ slopes. In the tree layer codominants are Quercus petraea agg., Carpinus betulus, Quercus cerris. Shrub layer is with low cover (0 to 30\%) and is formed by same tree species, as well as Crataegus monogyna and Cornus mas. Herbaceous layer is well-developed, formed by Poa nemoralis, Melica uniflora, Physospermum cornubiense, Mycelis muralis, Lathyrus laxiflorus, Potentilla micrantha. These forests origin is varied - seed and coppiced. The species composition is transitional including plants typical for other communities especially of alliances Erythronio-Carpinion and Quercion petraeocerridis.

Group 13. Association Genisto januensis-Quercetum pubescentis (Jakucs 1961) Tzonev et al. 2019 (Figure 2, relevé 99; Appendix 1, gr. 13)

Diagnostic species: Vinca herbacea (100), Veronica austriaca s.l. (100), Ranunculus millefoliatus (100), Polygala major (100), Plantago media (100), Jurinea consanguinea (100), Hypericum aucheri (100), Filipendula vulgaris (100), Ferulago sylvatica (100), Euphorbia agrarian (100), Cyanus thirkei (100), Carex liparocarpos (100), Ajuga laxmannii (95.1), Quercus pubescens (92.1), Comandra umbellata s.l. (92.1), Pyrus communis s.l. (90.7), Teucrium chamaedrys (88.2), Festuca valesiaca (84.1), Trifolium alpestre (80.2), Poa bulbosa (79.5), Sesleria latifolia (78.1), Cytisus hirsutus (78.1), Silene italica (77.3), Syringa vulgaris (75.1).

Constant species: Vincetoxicum hirundinaria (100), Polygonatum odoratum (100), Fritillaria pontica (100), Fraxinus ornus (100), Dactylis glomerata (100), Crataegus monogyna (100), Carpinus orientalis (100).

Dominant species: Quercus pubescens (100).

The association is represented by only one relevé. Its stand is located at about $570 \mathrm{~m}$ a.s.l., on dry and skeletal soils with rocky outcrops and moderately-steep (about $20^{\circ}$ ) slope with northern aspect. Quercus pubescens and Carpinus orientalis are dominant species in tree layer, while Syringa vulgaris prevails in shrub layer, and Sesleria latifolia in herbaceous layer.

The registered in the Slivenka Mt. phytocoenosis floristically is very similar to association Lithospermo purpureocaerulei-Quercetum pubescentis Michalko 1957 (alliance Aceri tatarici-Quercion), known from Romania (Coldea et al. 2015) and Hungary (Borhidi et al. 2012), and characterized by participation of continental species, as well as some submediterranean species, as Carpinus orientalis and Fraxinus ornus. Our stand is located southern than the main distribution region of the Lithospermo purpureocaerulei-Quercetum pubescenti association. Also our stand is characterized by more thermophilic condition, which leads to occurence of species of southern origin and distri- bution such as Hypericum aucherii, Cyanus thirkei, Carex liparocarpus and Sesleria latifolia. All these peculiarities gave us reason to classify this relevé rather to the described by Tzonev et al. (2019) association - Genisto januensisQuercetum pubescentis.

\section{Group 15. Association Arabio turritae-Carpinetum} orientalis Tzonev 2013 (Figure 2, relevés 110-115; Appendix 1, gr. 15)

Diagnostic species: Ruscus aculeatus (53.6), Lactuca hispida (52.6), Muscari botryoides (48.0), Trifolium scabrum (39.9), Tragopogon pratensis (39.9), Hypericum montbretii (39.9), Geranium divaricatum (39.9), Avenula pubescens (39.9), Arrhenatherum palaestinum (39.9), Alyssum turkestanicum (39.9), Achillea grandifolia (39.9), Prunus cerasifera (37.5), Arabis turrita (36.7), Carpinus orientalis (32.8), Euonymus verrucosus (31.9).

Constant species: Poa nemoralis (100), Fraxinus ornus (100), Acer campestre (83), Sorbus torminalis (67), Quercus petraea agg. (67), Cornus mas (67), Quercus frainetto (50), Melica uniflora (50), Dioscorea communis (50), Clinopodium vulgare (50).

Dominant species: Carpinus orientalis (100), Quercus pubescens (17), Cornus mas (17), Acer campestre (17).

Stands of this association are distributed on elevation of 450-950 $\mathrm{m}$ a.s.l. in the southern and southwestern part of the study area on moderately-steep slopes $\left(10\right.$ to $\left.40^{\circ}\right)$ with predominantly western aspect. Soils are Cambisols and Chromic Luvisols, poor to medium rich in nutrition, dry to fresh in moisture, strong to medium rocky, with erosion processes in some places.

The dominance of Carpinus orientalis is typical for this community type, but in one relevé Quercus pubescens is a dominant species (with cover of 50\%). Other species registered in the tree layer are Quercus frainetto, Q. petraea agg., Sorbus torminalis. Shrub layer is well-developed, formed by tree layer species, as well as Cornus mas, Crataegus monogyna, Rosa canina, Fraxinus ornus. Herbaceous layer is commonly poorly developed, with most abundant species as Poa nemoralis, Arabis turrita, Melica uniflora, Dioscorea communis, Viola hirta, Ruscus aculeatus, Hedera helix dominating.

Association Arabio turritae-Carpinetum orientalis has been described from the southern part of the Middle Danubian Plain, bounded by the Forebalkan (Tzonev 2013). The following diagnostic species have been described for the association - Arabis turrita, Campanula trachelium, Asplenieum trichomanes, Scilla bifolia, Isopyrum thalictroides, Corydalis bulbosa, Lamium galeobdolon, Polygonatum latifolium, Asperula taurina, Ranunculus villosus subsp. constantinopolitanus, Doronicum orientalis, Stachys sylvatica. 
Group 14. Community type Quercus petraea and Polygonatum latifolium (Figure 2, relevés 100-109; Appendix 1, gr. 14)

Diagnostic species: Laser trilobum (62.2), Polygonatum latifolium (52.3), Scutellaria columnae (43.7), Mercurialis ovata (43.7), Asparagus tenuifolius (43.7), Cornus mas (35.8), Tanacetum corymbosum (33.4), Carpinus orientalis (32.8), Buglossoides purpurocaerulea (31.4), Dioscorea communis (30.9), Ruscus aculeatus (30.1).

Constant species: Quercus petraea agg. (100), Physospermum cornubiense (90), Melica uniflora (90), Sorbus torminalis (80), Fraxinus ornus (70), Crataegus monogyna (70), Acer campestre (70), Tilia tomentosa (60), Poa nemoralis (60), Quercus cerris (50), Primula veris (50), Potentilla micrantha (50), Hedera helix (50) Campanula rapunculoides (50).

Dominant species: Carpinus orientalis (80), Quercus petraea agg. (70), Tilia tomentosa (10), Quercus cerris (10), Fraxinus ornus (10), Fraxinus excelsior (10), Corylus colurna (10).

This community type differs from the others of alliance Carpinion orientalis because it is developed mostly on the limestone. Its stands occure on elevation between 300 and $850 \mathrm{~m}$, on sunny slopes with a predominantly eastern aspect. Soils are Chromic Luvisols and Rendzinas, dry to fresh in moisture, poor to medium rich in nutrition eroded in some places. The vertical structure is presented by well-developed 3 layers. Tree layer is dominated by Quercus petraea agg. and Carpinus orientalis but Quercus cerris, Q. frainetto, Corylus colurna and Tilia tomentosa also occur. In some places, the canopy of tree layer is opened (about 50\%). Shrub layer is formed by Cornus mas, Crataegus monogyna, Fraxinus ornus, Sorbus torminalis, Acer campestre. Often, Carpinus orientalis participates in the shrub layer too, or forms a second tree layer. The herbaceous layer species composition is very rich and diverse, where the most common species are Melica uniflora, Poa nemoralis, Lathyrus niger, Hedera helix. These forests in the study area, is mainly coppiced, formed as a result of logging activities. A preserved high forests exist in some places and they are used predominantly as a leaf fodder.

The floristic composition of this group communities is similar to the association Lathyro nigri-Quercetum petraeae Horvat (1938) 1959 which is widespread in the Western Balkans (Stupar et al. 2015). This association is characterized by a relatively high frequency of Acer $o b$ tusatum, Sesleria autumnalis and Cyclamen purpurascens, species not found in Bulgaria. Another significant difference is that in the tree layer of the community Quercus petraea and Polygonatum latifolium, the main dominant is Carpinus orientalis along Quercus petraea.
Groups 16-18. Association Genisto carinalis-Quercetum petraeae Bergmeier in Bergmeier et Dimopoulos 2008 (Figure 2, relevés 116-137; Appendix 1, gr. 16-18) Diagnostic species: Viscaria vulgaris (62.1), Festuca heterophylla (49.3), Pilosella officinarum agg. (43.8), Hypericum perforatum (38.1), Galium album (37.0), Verbascum humile (35.8), Quercus petraea agg. (35.2), Luzula luzuloides (34.9), Fraxinus ornus (30.6).

Constant species: Poa nemoralis (86), Carpinus orientalis (82), Melica uniflora (55), Campanula persicifolia (55), Potentilla micrantha (50), Lathyrus laxiflorus (45), Dactylis glomerata (45), Quercus frainetto (41), Lactuca muralis (41).

Dominant species: Quercus petraea agg. (100), Carpinus orientalis (23), Poa nemoralis (14), Fagus sylvatica (14), Quercus frainetto (9), Quercus cerris (5), Luzula luzuloides (5).

The stands of association Genisto carinalis-Quercetum petraeae occur on quartz or sandstone bedrocks, and rocky, shallow to moderately-deep Cambisols and Chromic Luvisols soils, and elevation between 500 and $1000 \mathrm{~m}$. Western and southern facing aspect prevail. Slopes are moderately-steep (between 10 and $35^{\circ}$ ). These forests are predominantly of coppiced origin, but in some places single old individuals with seed origin are preserved. The canopy of a tree layer varies between $40-90 \%$. Open-canopy forests are located on drier and rougher places.

Quercus petraea agg. dominates in the tree layer. Other tree species recorded in these phytocoenoses are Quercus frainetto, Fagus sylvatica, Carpinus betulus, C. orientalis, Sorbus torminalis. Shrub layer is represented by young trees of above mentioned species, as well as Crataegus monogyna and Fraxinus ornus. In some stands, shrub layer is not well-developed or is missing, due to the high tree layer canopy. In some communities, Carpinus orientalis is also a dominant species in shrub layer. Herbaceous layer is usually well developed with high species diversity, where the most frequent species are Poa nemoralis, Melica uniflora, Dactylis glomerata, Luzula luzuloides, Campanula persicifolia, Lathyrus laxiflorus, L. niger, Galium album, Euphorbia amygdaloides, Hypericum perforatum, Viscaria vulgaris, Potentilla micrantha, Clinopodium vulgare.

Association Genisto carinalis-Quercetum petraeae has been described from the northern Greece within the alliance Quercion confertae Horvat 1954 (Bergmeier \& Dimopoulos 2008). Gogushev (2009) refers Quercus petraea agg. forests from the Western Frontier Mountains to this association but classifies it in alliance Quercion pubescentisessiliflorae Br.-Bl. 1932. Pachedjieva \& Georgieva (2010) also classifed forests of Quercus petraea agg. from the Kamenshtitsa Reserve to this association but refer it to the alliance Quercion petraeae Zólyomi et Jakucs in Soó 
1963, which is widespread in Central Europe (Mucina et al. 2016). The following diagnostic species have been described for the association in different literature sources - Quercus petraea agg., Fagus sylvatica, Carpinus betulus, Campanula persicifolia, C. trachelium subsp. athoa, Cystopteris fragilis, Dactylis glomerata, Epipactis atrorubens, Euphorbia amygdaloides, Hypericum perforatum, Poa nemoralis, Potentilla micrantha, Silene atropurpurea, Veronica chamaedrys.

For the territory of Romania, 6 associations dominated by Quercus petraea agg. (Coldea et al. 2015) are known, and 3 of them are listed under alliance Quercion frainetto Horvat I. 1954, while the other 3 are classified to alliance Quercion petraeae Zólyomi et Jakucs 1957. Numerous of diagnostic species for all six associations have also been recorded in studied communities. In Serbia, 5 associations, with Quercus petraea agg. are referred to alliance Quercion petraeae-cerris Lakšć. et Jov. 1980 - continental Quercus petraea agg. and Quercus cerris forest vegetation (Kojić et al. 1998).

After the floristic and ecological comparisons, we assumed that these oak communities from the territory of the Slivenska Mt. are most similar in species composition and ecological characteristics to the association Genisto carinalis-Quercetum petraeae Bergmeier in Bergmeier et Dimopoulos 2008. The association was recorded till now in other region of Bulgaria, like southwestern Bulgaria (Gogushev 2009), the Central Stara Planina Mt. in the Kamenshtitsa Reserve (Pachedjieva \& Georgieva 2010) and the Eastern Stara Planina Mt. (Tzonev et al. 2019).

We recognized 3 variants of the association regarding floristic and ecological characteristics.

Group 17. Variant typicum (Figure 2, relevés 121-131; Appendix 1, gr. 17)

Diagnostic species: Galium album (49.8), Allium flavum (41.6).

Constant species: Quercus petraea agg. (100), Fraxinus ornus (100), Potentilla micrantha (91), Poa nemoralis (91), Carpinus orientalis (91), Melica uniflora (82), Luzula luzuloides (73), Lactuca muralis (73), Lathyrus laxiflorus (64), Campanula persicifolia (64), Lathyrus niger (55), Dactylis glomerata (55), Sorbus torminalis (45), Quercus frainetto (45), Fagus sylvatica (45), Euphorbia amygdaloides (45), Cruciata glabra (45), Carpinus betulus (45), Acer campestre (45).

Dominant species: Quercus petraea agg. (100), Carpinus orientalis (27), Poa nemoralis (18), Fagus sylvatica (18), Quercus frainetto (9), Quercus cerris (9).

This variant is more mesophytic and represented the main association characteristics.
Group 16. Variant Verbascum bumile (Figure 2, relevés 116-120; Appendix 1, gr. 16)

Diagnostic species: Verbascum humile (76.6), Cota tinctoria (71.3), Pilosella officinarum agg. (63.3), Odontarrhena muralis (62.2), Minuartia verna (62.2), Hylotelephium maximum (62.2), Euphorbia myrsinites (62.2), Hypericum perforatum (59.7), Euphorbia cyparissias (56.0), Viscaria vulgaris (53.3), Achillea millefolium agg. (51.2), Viola kitaibeliana (43.7), Silene compacta (43.7), Scabiosa triniifolia (43.7), Pilosella piloselloides (43.7), Phleum phleoides (43.7), Minuartia hirsuta s.l. (43.7), Lysimachia vulgaris (43.7), Koeleria splendens (43.7), Jasione montana (43.7), Genista lydia (43.7), Fumaria vaillantii (43.7), Fallopia convolvulus (43.7), Carex melanostachya (43.7), Campanula sibirica (43.7), Bellardiochloa variegata (43.7), Anthoxanthum odoratum (43.7), Anthemis cretica s.l. (43.7), Anisantha tectorum (43.7), Allium sphaerocephalon (43.7), Achillea clypeolata (43.7), Rumex acetosella (34.7), Stellaria holostea (30.3).

Constant species: Quercus petraea agg. (100), Fraxinus ornus (100), Sorbus torminalis (60), Poa nemoralis (60), Dactylis glomerata (60), Carpinus orientalis (60).

Dominant species: Quercus petraea agg. (100), Carpinus orientalis (40).

This variant community is the most xerophytic. Soils are dry, very poor in nutrition and stony. Slopes are steep (about $35^{\circ}$ ), west and south facing.

Group 18. Variant Festuca heterophylla (Figure 2, relevés 132-137; Appendix 1, gr. 18)

Diagnostic species: Silene viridiflora (56.6), Dianthus moesiacus (56.6), Galium pseudaristatum (48.9), Avenella flexuosa (48.3), Festuca heterophylla (46.7), Viscaria vulgaris (43.0), Pilosella baubinia (39.9), Minuartia recurva (39.9), Luzula luzuloides (39.9), Galium paschale (39.9), Apium graveolens (39.9), Acer tataricum (39.9), Pilosella officinarum agg. (36.8), Hieracium murorum (35.9), Cytisus hirsutus (35.3).

Constant species: Quercus petraea agg. (100), Poa nemoralis (100), Fraxinus ornus (83), Carpinus orientalis (83), Campanula persicifolia (67), Veronica chamaedrys (50), Melica uniflora (50), Lathyrus laxiflorus (50).

Dominant species: Quercus petraea agg. (100), Quercus frainetto (17), Poa nemoralis (17), Luzula luzuloides (17), Fagus sylvatica (17).

This variant has a transitional character between the previous two, but with rather closer features of species composition and environmental conditions to the variant typicum. 


\section{Conclusions}

Natural and semi-natural forest phytocoenoses occupy about $80.4 \%$ of the territory of the Slivenska Mt. These forests are responsible for numerous ecosystems' services, such as biodiversity conservation, anti-erosion and shore protection, recreation and tourism, timber logging, etc. The high conservation significance of the studied area is further emphasized by their inclusion in protected areas (52.6\% of the area of the study territory), which management leads to maintaining the vegetation in good condition and close to the natural. The present study is the first detailed research of forest vegetation on the territory of the Slivenska Mt., according to the Braun-Blanquet approach. Largest areas are occupied by forest communities of class Carpino-Fagetea sylvaticae. Some phytocenoses still were not assigned to the associations, because of their local occurrence or limited data of their presence in other regions of Bulgaria. However, this research, proposed the most actual classification scheme for the forest vegetation of the Slivenska Mt., especially on the alliance level. The recorded 18 dinguished vegetation groups show a relatively high diversity of forest plant communities of the study area.

\section{Acknoweldgements}

The study is a part of continuing work under the projects "Study of flora and vegetation of the Slivenska Mts - stage I and II" funded by Scientific research sector of University of Forestry, Sofia.

Marius Dimitrov (D), https://orcid.org/0000-0002-2632-7883 Kiril Vassilev (D), https://orcid.org/0000-0003-4376-5575 Desislava Sopotlieva (D, https://orcid.org/0000-0002-9281-7039 Hristo Pedashenko Di, https://orcid.org/0000-0002-6743-0625 Alexander Tashev (D), https://orcid.org/0000-0002-1979-2568

\section{References}

Agrolesproject. 2012: Forest Management Plan of State Forestry Unit Sliven [in Bulgarian].

Agrolesproject. 2014: Forest Management Plan of State Forestry Unit Kotel [in Bulgarian].

Andreev, N. 1981: Botanical Characteristics of Sinite Kamani Natural Park. In: Management plan of Sinite Kamani Natural Park. Agrolesproekt, Sofia [in Bulgarian].

Apostolova, I. \& Slavova, L. 1997: Conspectus of plant communities in Bulgaria, published during the period 1891-1995. Print ET "K. Belivanov", Sofia, 340 pp. [in Bulgarian].

Apostolova-Stoyanova, N., Pavlov, D. \& Dimitrov, M. 2005: Study on the syntaxonomic diversity of vegetation in northwestern parts of the Golo Bardo Mountain. In: Brezin, V., Tasev, G., Panayotov, P.,
Zdravkova-Milusheva, M. \& Krasteva, A. (eds). 2005: Proc. Natl. Conf. Young Sci. University of Forestry Press, Sofia, pp 26-31, [in Bulgarian].

Bergmeier, E. \& Dimopoulos, P. 2008: Identifying plant communities of thermophilous deciduous forest in Greece: Species composition, distribution, ecology and syntaxonomy. Plant Biosystems 142: 228-254.

Biondi, E., Blasi, C., Allegrezza, M., Anzellotti, I., Azzella, M. M., Carli, E., Casavecchia, S., Copiz, R., Del Vico, E., Facioni, L., Galdenzi, D., Gasparri, R., Lasen, C., Pesaresi, S., Poldini, L., Sburlino, G., Taffetani, F., Vagge, I., Zitti, S. \& Zivkovic, L. 2014: Plant communities of Italy: The Vegetation Prodrome. Plant Biosystems 148(4): 728-814.

Bondev I. 1991: The vegetation of Bulgaria. Map in M $1: 600000$ with explanatory text, Sofia, 184 pp., [in Bulgarian].

Bondev, I. 2002: Geobotanical regioning. In: Kopralev, I., Yordanova, M., Mladenov, Ch. (eds.). 2002: Geography of Bulgaria. Physical and socio-economic geography. ForKom, Sofia, pp. 336-352, [in Bulgarian].

Borhidi, A., Kevey, B. \& Lendvai, G. 2012: Plant communities of Hungary. Akadémiai Kiadó, Budapest, 525 pp.

Braun-Blanquet, J. 1964: Pflanzensoziologie - Grundziige der Vcgetationskunde, Wien, New York, 865 pp.

Burescu, P. \& Lacatos, L. M. 2010: Contributions to the knowledge of hornbeam and beech forests, from Lazareni hills (NW Romania). Analele Universității din Oradea - Fascicula Biologie 27: 55-61.

Čarni, A. 2016a: Vegetation of deciduous forests in the Balkan Peninsula. Contributions, Section of Natural, Mathematical and Biotechnical Sciences, MASA 37(2): 93-104.

Čarni, A. 2016b: Xero-thermophilous broad-leaved ravine forests of SE Europe. In: Willner, W., Solomeshch, A., Čarni, A., Bergmeier, E., Ermakov, N. \& Mucina, L. 2016: Description and validation of some European forest syntaxa - a supplement to the EuroVegChecklist. Hacquetia 15(1): 15-25.

Čarni, A., Košir, P., Karadžić, B., Matevski, V., Redžić, S. \& Škvorc, Ž. 2009: Thermophilous deciduous forests in Southeastern Europe. Plant Biosystems 143: 1-13.

Chytrý, M. \& Otýpková, Z. 2003: Plot sizes used for phytosociological sampling of European vegetation. Journal of Vegetation Science 14(4): 563-570.

Chytrý, M., (ed.). 2013: Vegetation of the Czech Republic 4. Forest and Scrub Vegetation. Vyd. 1. Academia, Praha, 551 pp.

Chytrý, M., Tichý, L. \& Holt, J. 2006: The Fidelity Concept. In: Tichý, L. \& Holt, J. (eds.): Juice program for management, analysis and classification of ecological data. Program manual, Vegetation Science Group, Masaryk University, Brno, pp. 45-54.

Chytrý, M., Tichý, L., Holt, J. \& Botta-Dukát, Z. 2002: Determination of diagnostic species with statistical fidelity measures. Journal of Vegetation Science 13: 79-90.

Coldea, G. 1991: Prodrome des associations végétales des Carpates du sud-est (Carpates Roumaines), Documents phytosociologiques., Camerino 13: 447-539.

Coldea, G. (ed.), Indreica, A. \& Oprea, A. 2015: Les associations végétales de Roumanie. Tome 3. Les associations forestiéres et arbustives. Presa Universitară Clujeană \& Accent, Cluj-Napoca, 282 pp.

Dimitrov, M., Pavlov, D., Glogov, P. \& Yordanova, D. 2004: Study on changes of vegetation in territories with continued antropogenic influence in the Vitosha Natural Park. Nauka za Gorata 3: 57-75, [in Bulgarian]. 
Douda, J., Boublik, K., Slezák, M., Biurrun, I., Nociar, J., Havrdová, A., Doudová, J., Aćić, S., Brisse, H., Brunet, J., Chytrý, M., Claessens H., Csiky, J., Didukh, Y., Dimopoulos, P., Dullinger, S., Fitz Patrick, Ú., Guisan, A., Horchler, P. J., Hrivnák, R., Jandt, U., Kącki, Z., Kevey, B., Landuci, F., Lecomte, H., Lenoir, J., Paal, J., Paternoster, D., Pauli, H., Pielech, R., Rodwell, J. S., Roelandt, B., Svenning, J. C., Šibík, J., Šilc, U., Škvorc, Ž., Tsiripidis, I., Tzonev, R. T., Wohlgemuth, T., \& Zimmermann, N. E. 2016: Vegetation classification and biogeography of European floodplain forests and alder carrs. Applied Vegetation Science 19: 147-163.

Gogushev G. 2009: Floristic classification of oak forests in the Western Frontier Mountains. Forestry Ideas 1(37): 54-77 [in Bulgarian].

Hennekens, S. \& Schaminée, J. 2001: TURBOVEG, a comprehensive database management system for vegetation data. Journal of Vegetation Science 12(4): 589-591.

Horvat, I., Glavač, V. \& Ellenberg, H. 1974: Vegetation Südosteuropas. Gustav Fischer Verlag, Jena/Stuttgart, 768 pp. http://www.emplantbase.org/home.html

Kojić, M., Popović, R. \& Karadžić, B. 1998: Sintaksonomski pregled vegetacije Srbije. Institut za biološka istraživanja "Siniša Stanković", Beograd, 220 pp.

Matevski, V., Čarni, A., Avramoski, O., Juvan, N., Kostadinovski, M., Košir P., Marinšek, A., Paušič, A. \& Šilc, U. 2011: Forest vegetation of the Galičica mountain range in Macedonia. ZRC SAZU, Biološki inštitut Jovana Hadžija, Makedonska akademija na naukite i umetnostite, Ljubljana, 200 pp.

McCune, B. \& Mefford, M. J. 1999: PC-ORD. Multivariate analysis of ecological data. Version 4. MjM Software design, Gleneden Beach.

Mucina, L., Bültmann, H., Dierßen, K., Theurillat, J.P., Raus, T., Čarni, A., Šumberová, K., Willner, W., Dengler, J., García, R. G., Chytrý, M., Hájek, M., Pietro, R.D., Iakushenko, D., Pallas, J., Daniëls, F. J. A., Bergmeier, E., Guerra, A. S., Ermakov, N., Valachovič, M., Schaminée, J. H. J., Lysenko, T., Didukh, Y. P., Pignatti, S., Rodwell, J. S., Capelo, J., Weber, H. E., Solomeshch, A., Dimopoulos, P., Aguiar, C., Hennekens, S. M. \& Tichý, L. 2016: Vegetation of Europe: hierarchical floristic classification system of vascular plant, bryophyte, lichen, and algal communities. Applied Vegetation Science 19: 3-264.

Ninov, N. 2002: Soils. In: Kopralev, I., Yordanova, M. \& Mladenov, Ch. (eds.). 2002: Geography of Bulgaria. Physical and socio-economic geography. ForKom, Sofia, pp. 277-315 [in Bulgarian].

Pachedjieva, K. \& Georgieva, N. 2010: Landscape diversity in Central Stara planina Mountain around the upper and middle stream of Eninska river. In: Sbornik mladejka nauchna konferencia "Klimentovi dni” 22-23 November 2010, Sofia.

Peev, D., Petrova, A., Apostolova, I. \& Assyov, B. 2012: Important plant areas in Bulgaria. Pensoft. Sofia Moscow, 469 pp.

Roleček, J. 2005: Vegetation types of dry-mesic oak forests in Slovakia. Preslia 77, pp. 241-261.

Sokal, R. R. \& Rohlf, F. J. 1995: Biometry. 3rd edition. W. H. Freeman and company, New York, 887 pp.

Soó, R. 1964: Die regionalen Fagion-Verbande und Gesellschaften Südosteuropas. Stud. Biol. Hung. 1: 5-104.

Sopotlieva, D., Pedashenko, H., Alexandrova, A. \& Ganeva, A. 2016: Flora, vegetation and natural habitat types in Kutelka Reserve (Eastern Stara Planina, Bulgaria). Phytologia Balcanica 22(3): 387-404.

Steffanov, P. 2002: Morphographic characteristics. In: Kopralev, I. Yordanova, M. \& Mladenov, Ch. (eds.). 2002: Geography of Bulgaria. Physical and socio-economic geography. ForKom, Sofia, pp. 29-38 [in Bulgarian].
Stoeva, M. 2004: Vegetation in Sinite Kamani Nature Park. In: Stoeva, M., Stoychev, G., Mladenov, R., Grozeva, N., Stoeva-Hristova, K., Velichkova, K., Georgieva, M. \& Valkova, M. 2004: Biological Diversity in Sinite Kamani Nature Park. Stara Zagora, 218 pp. [in Bulgarian].

Stoyanov, N. 1941: An attempt for characteristic of main phytocoenoses in Bulgaria. Yearbook of Sofia University, Faculty of Physics and Mathematics 37: 93-194 [in Bulgarian].

Stupar, V., Milanović, Đ., Brujić, J. \& Čarni, A. 2015: Formalized classification and nomenclatural revision of thermophilous deciduous forests (Quercetalia pubescentis) of Bosnia and Herzegovina. Tuexenia 35: 85-130.

Tichý, L. 2002: JUICE, software for vegetation classification. Journal of Vegetation Science 13: 451-453.

Trass, H. 1976: Geobotany. History and modern development trends. Leningrad, Science, 252 pp. [in Russian].

Tzonev, R. 2013: New plant associations from Danubian Plain, Bulgaria. Phytologia Balcanica 19(2): 243-266.

Tzonev, R., Dimitrov, M., Gussev, Ch., Pachedjieva, K., Gogushev, G., Apostolova-Stoyanova, N., Nikolov, I., Alexandrova, A. \& Glogov, P. 2019: Phytosociological classification of the thermophilous oak forests in Bulgaria: new interpretation and gaps in knowledge. Phytocoenologia 49(4): 369-391.

Tzonev, R., Dimitrov, M., Chytrý, M., Roussakova, V., Dimova, D., Gussev, C., Pavlov, D., Vulchev, V., Vitkova, A., Gogushev, G., Nikolov, I., Borisova, D. \& Ganeva, A. 2006: Beech forest communities in Bulgaria. Phytocoenologia 36(2): 247-279.

Tzonev, R., Dimitrov, M. \& Roussakova, V. 2009: Syntaxa according to the Braun-Blanquet approach in Bulgaria. Phytologia Balcanica 15(2): 209-233.

Vassilev, K., Pedashenko, H., Alexandrova, A., Tashev, A., Ganeva, A., Gavrilova, A., Gradevska, A., Assenov, A., Vitkova, A., Grigorov, B., Gussev, Ch., Filipova, E., Aneva, I., Knollova, I., Nikolov, I., Georgiev, G., Gogushev, G., Tinchev, G., Pachedjieva, K., Koev, K., Lyubenova, M., Dimitrov, M., Apostolova-Stoyanova, N., Velev, N., Zhelev, P., Glogov, P., Natcheva, R., Tzonev, R., Boch, S., Hennekens, S., Georgiev, S., Stoyanov, S., Karakiev, T., Kalnikova, V., Shivarov, V., Russakova, V. \& Vulchev, V. 2016: Balkan Vegetation Database: historical background, current status and future perspectives. Phytocoenologia 46(1): 89-95.

Velev, S. 2002: Climatic regioning. In: Kopralev, I., Yordanova, M. \& Mladenov, Ch. (eds.). 2002: Geography of Bulgaria. Physical and socioeconomic geography. ForKom, Sofia, pp. 155-156 [in Bulgarian].

Willner, W., Jiménez-Alfaro, B., Agrillo, E., Biurrun, I., Campos, J.A., Čarni, A., Casella, L., Csiky, J., Cušsterevska, R., Didukh, Y.P., Ewald, J., Jandt, U., Jansen, F., Kącki, Z., Kavgaci, A., Lenoir, J., Marinšek, A., Onyshchenko, V., Rodwell, J.S., Schaminée, J.H.J., Šibík, J., Škvorc, Ž., Svenning, J.-C., Tsiripidis, I., Turtureanu, P.D., Tzonev, R., Vassilev, K., Venanzoni, R., Wohlgemuth, T. \& Chytrý, M. 2017: Classification of European beech forests: a Gordian Knot? Applied Vegetation Science 20(3): 494-512.

Yordanova, M, Velev, S. \& Drenovski, I. 2002: Characteristic features of the physical geographical regions. In: Kopralev, I., Yordanova, M. \& Mladenov, Ch. (eds.). 2002: Geography of Bulgaria. Physical and socio-economic geography. ForKom, Sofia, pp. 391-410 [in Bulgarian]

Yordanova, M. 2002: Hydrological regioning. In: Kopralev, I., Yordanova, M., Mladenov, Ch. (eds.). 2002: Geography of Bulgaria. Physical and socio-economic geography. ForKom, Sofia, pp. 242-246 [in Bulgarian]. 


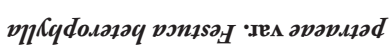
unıasıวก

unगIdא :IEA apapuad

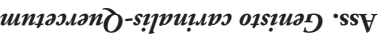

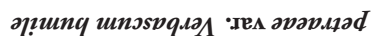

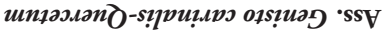

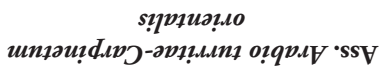

un!1of?

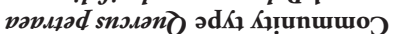

s!ฺuวssaqnd

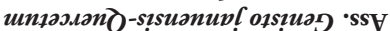

\section{papuzad snsuand}

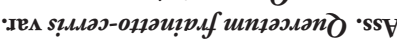

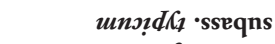

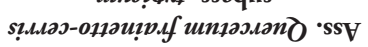

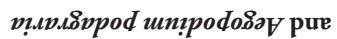
psou!nท

\section{apsoาuวmoт

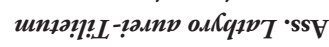

unıp!|ofiad mn!uıKus pue

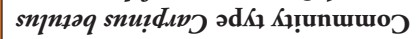

nonqpajאs skqpwis pue

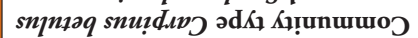

v.af?q1nq au!uvpıpว pue

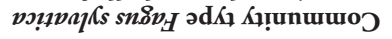

2
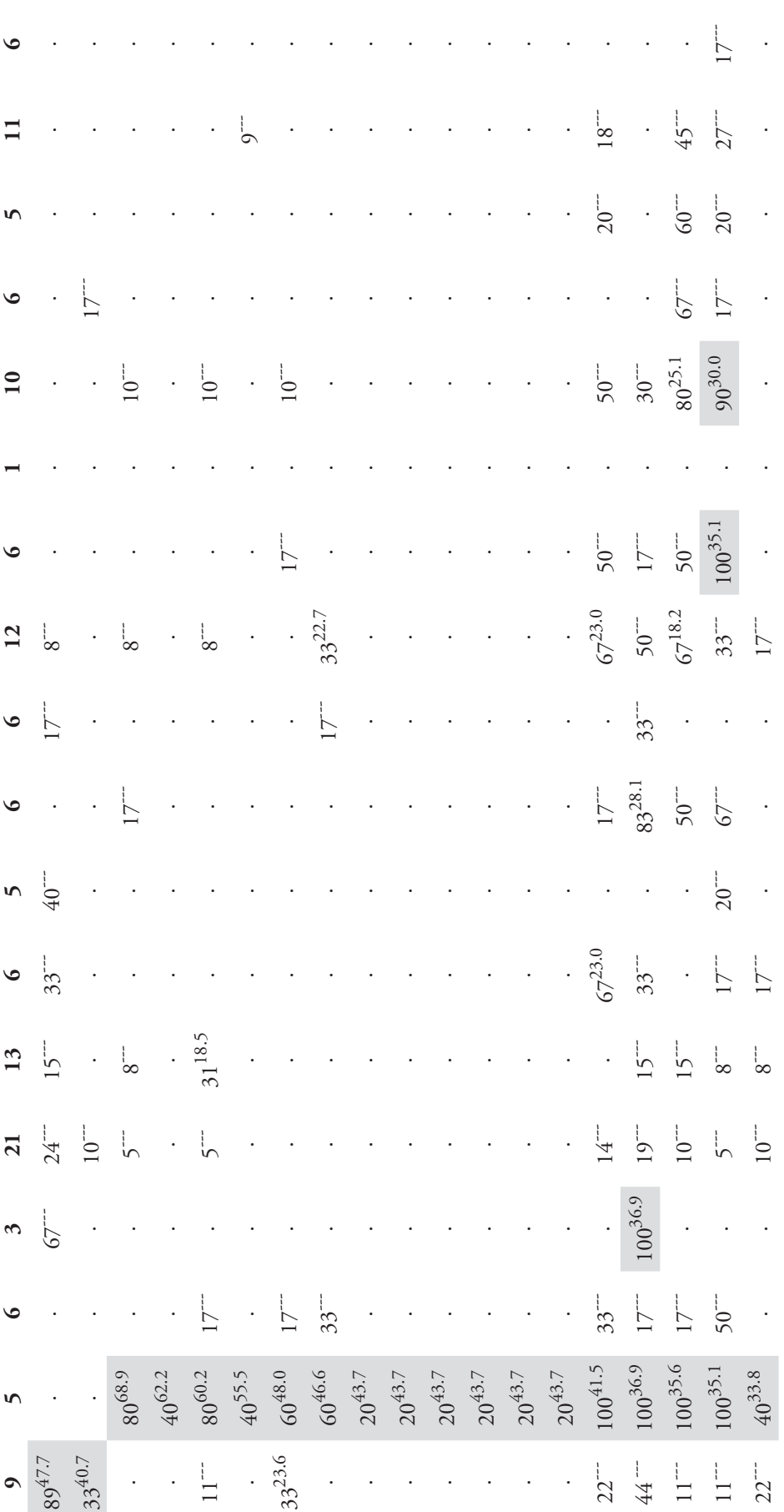

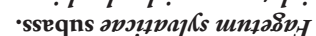

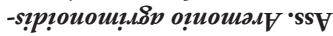

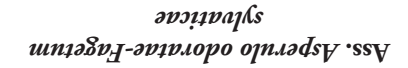

as

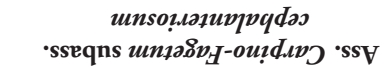

aps!npajks

unฺว80

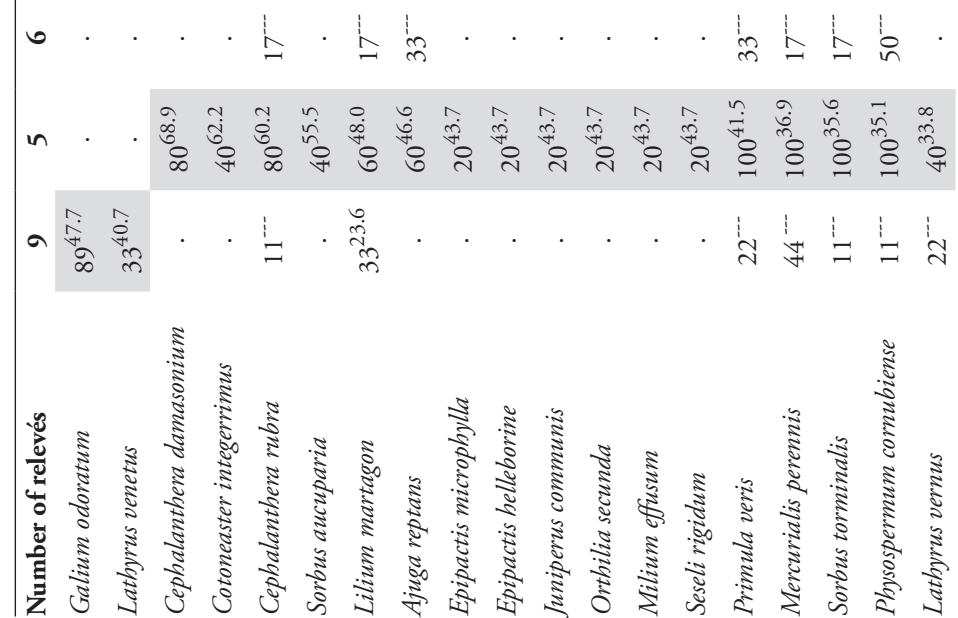


선 $h h_{\infty} \infty \cdot \cdot b$

$m$

in o :

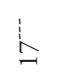

$\ln m$

तुํำ

$=1$

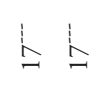

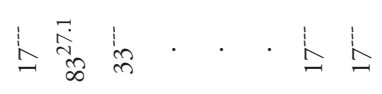

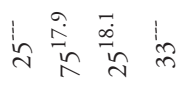

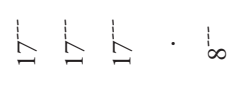

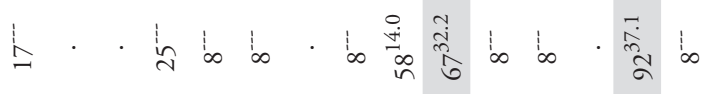

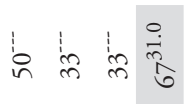

$\therefore=\stackrel{i}{i}_{i n}^{\infty}$

$\stackrel{\infty}{i} \cdot \operatorname{in}=$

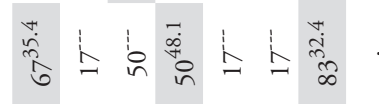

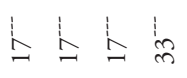

$\leq . \leq \stackrel{i}{i}_{\text {in }}$ i

m

के के : के

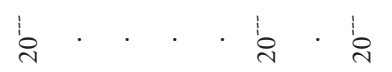

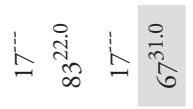

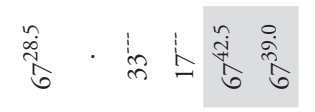

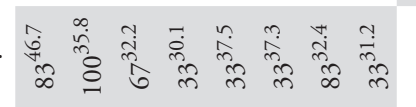

$\infty \begin{array}{lll}\infty & \infty & \infty\end{array}$

$\left.b_{\infty} \cdot b_{\infty}\right|_{i} \cdot b_{\infty} \cdot b_{\infty}$

$\because \underset{4}{4}$.

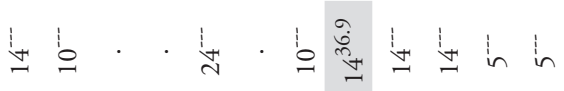

to

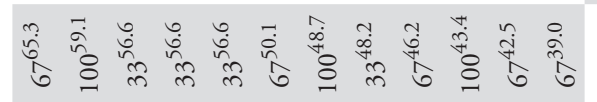

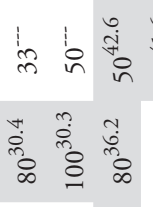

$m=\infty$

. $=\cdot$ in

ปิ

$\frac{4}{4}$

$\overrightarrow{1}$
నై
$\infty$

8

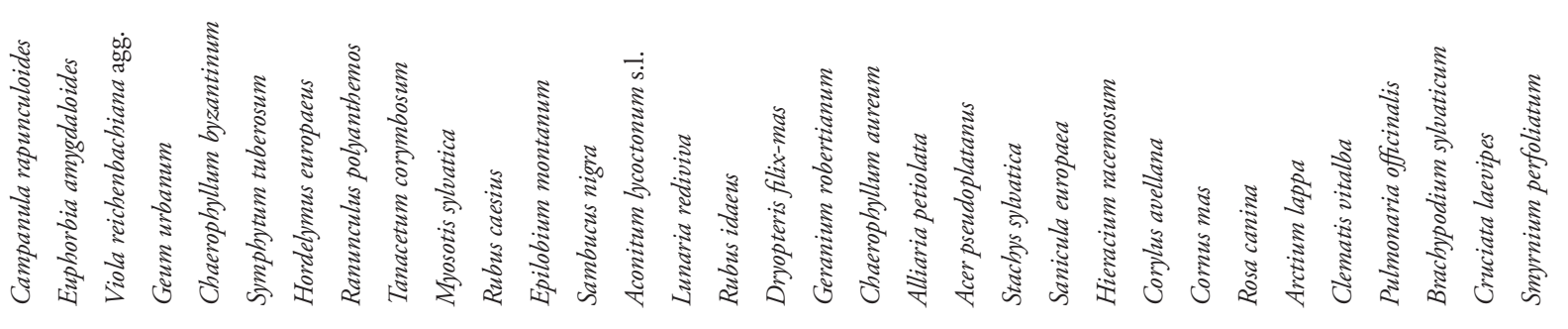


$\cong$

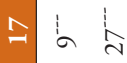

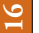

i

$\because$.

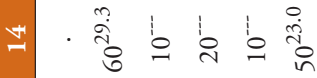

인

$\cong$

은

in $\cdot$.

$\therefore \cdot m$

$a \cdot+\cdot \cdot \infty_{\infty}$

$\infty \_\infty b_{\infty}$

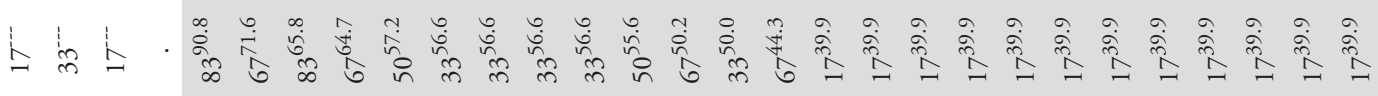

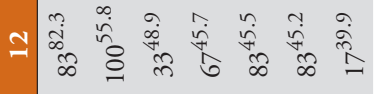

$=\cdot$. ำ

$m=L \cdot L \cdot \stackrel{m}{m}$

$m \cdot 1$

$\infty b_{\infty} \cdot b_{\infty}$

in $\cdot \stackrel{\stackrel{\circ}{\mathrm{d}}}{\stackrel{m}{m}}$ in

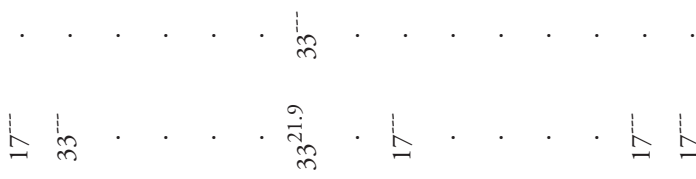

4)

i

$=\cdot \frac{4}{1}$

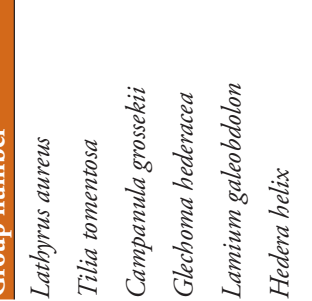

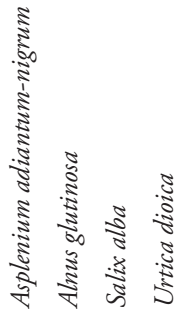

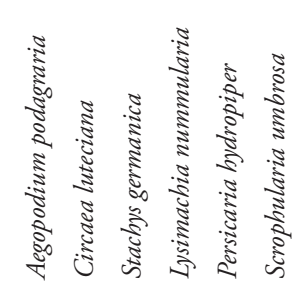

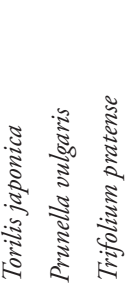

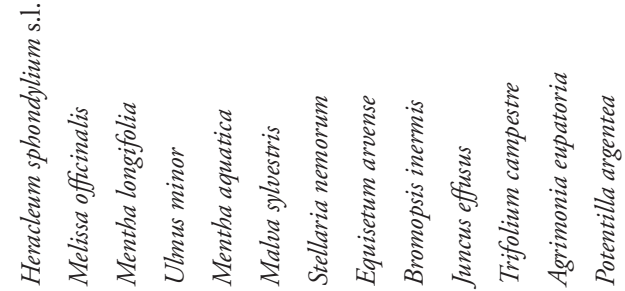




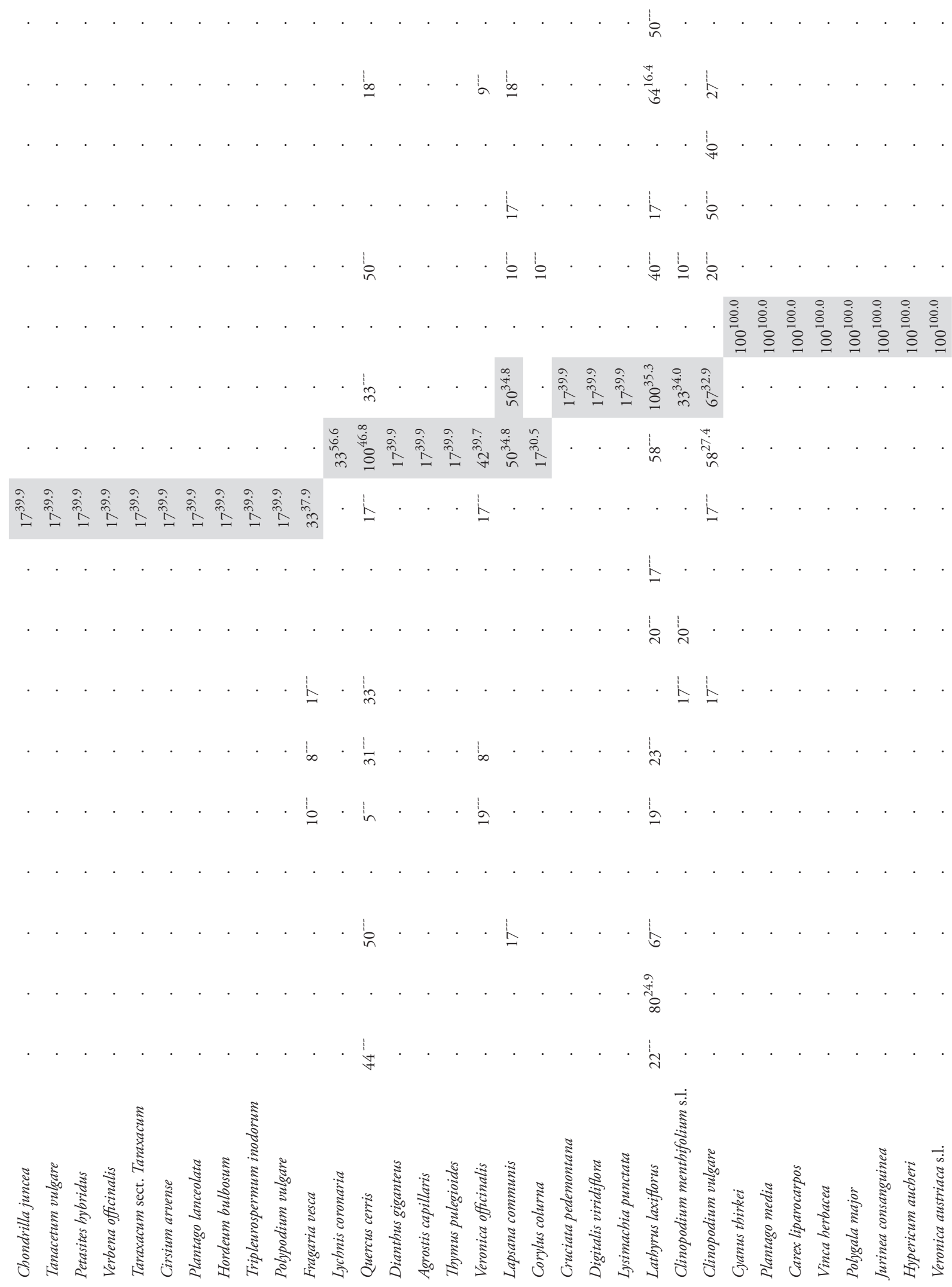




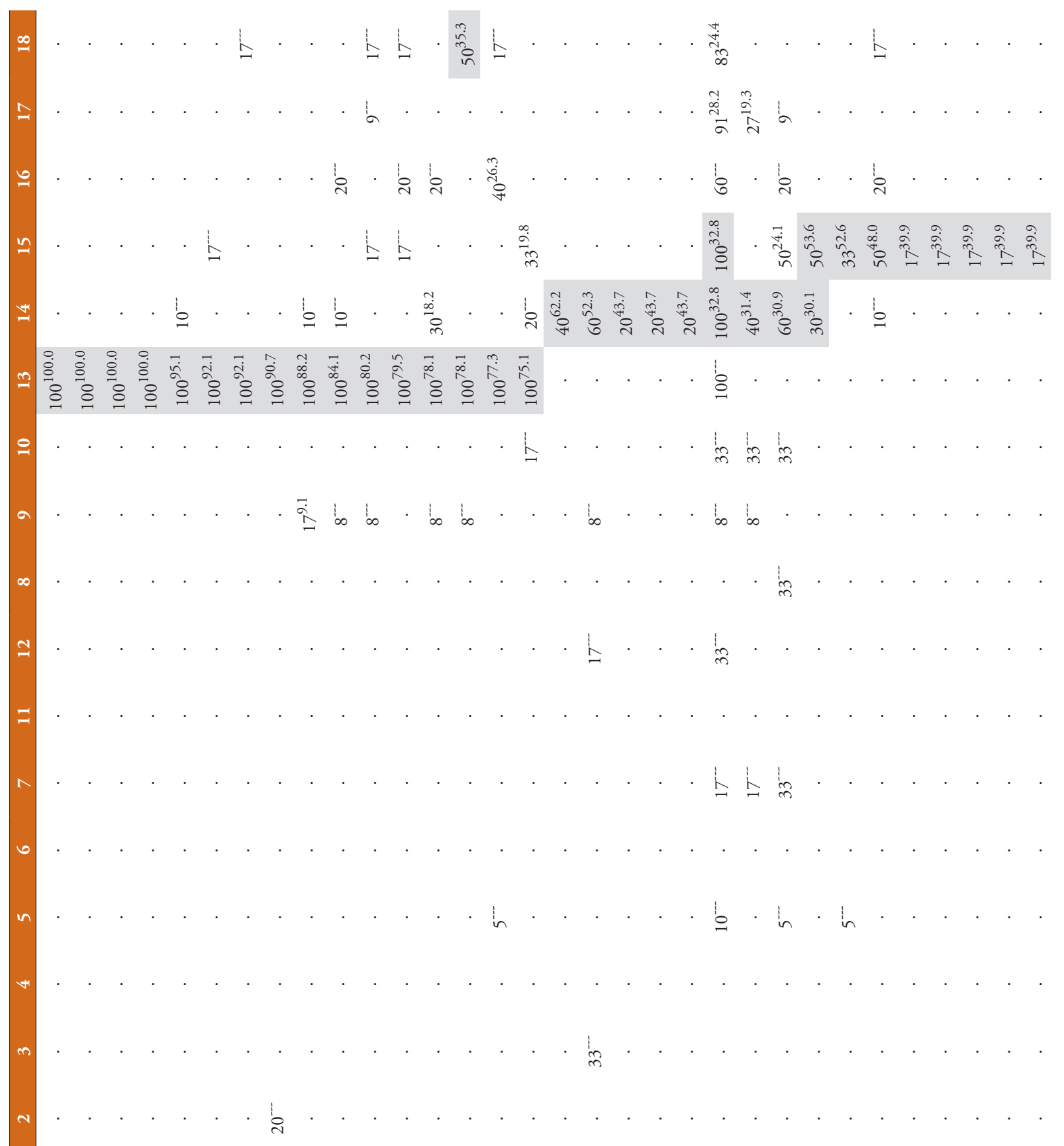




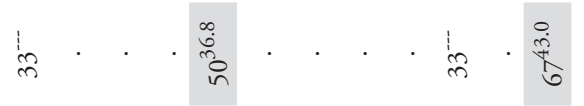

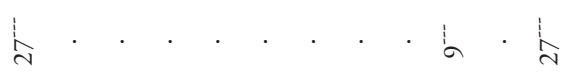

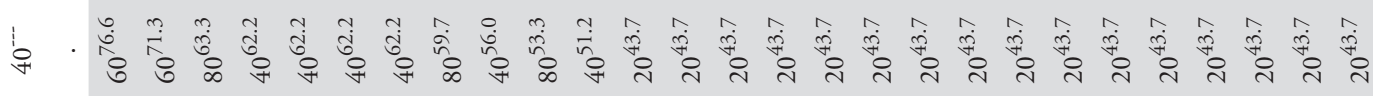

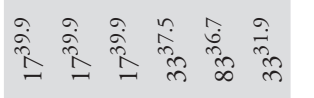

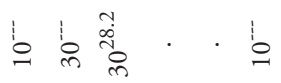

$$
\begin{aligned}
& \text { in }
\end{aligned}
$$

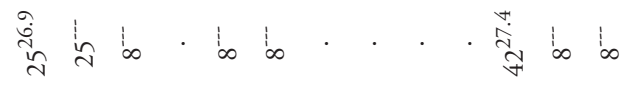

$$
\begin{aligned}
& \text { in } \\
& \text { ì } \\
& \text { ì }
\end{aligned}
$$

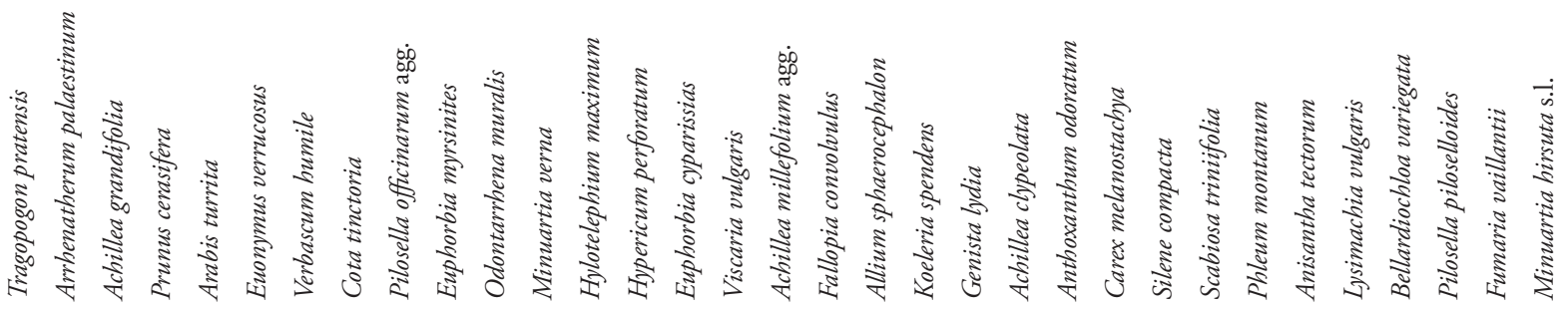




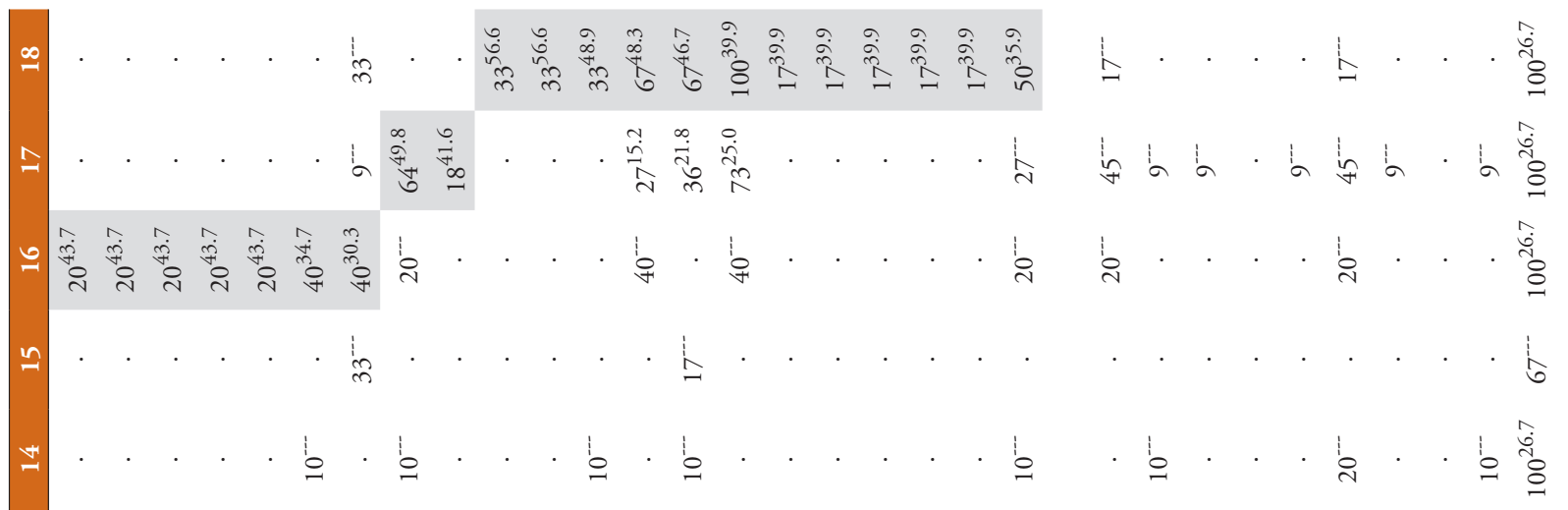




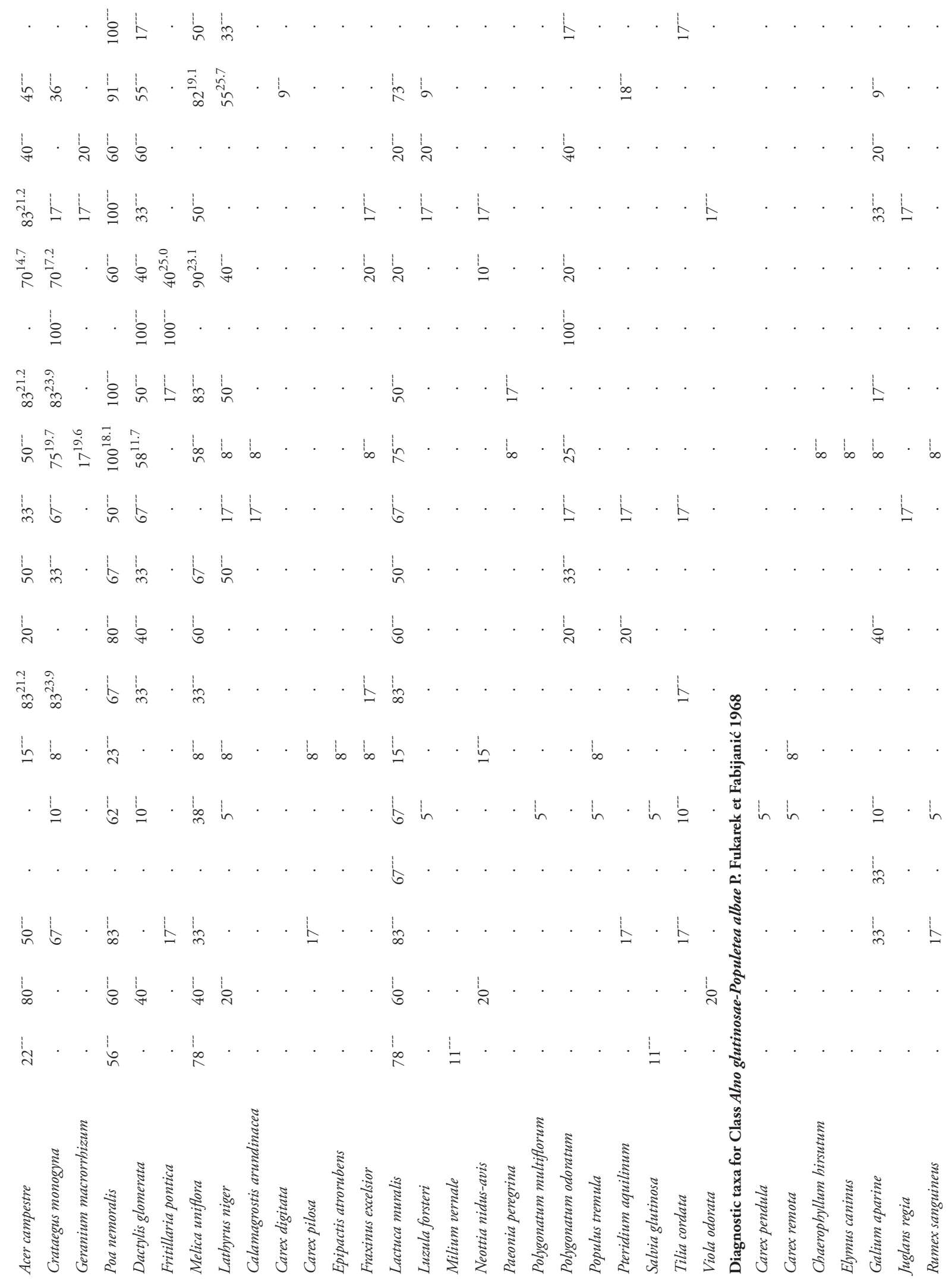




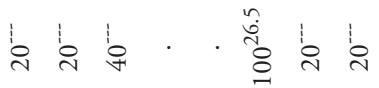

i్

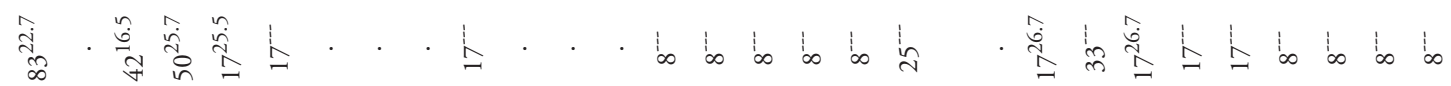




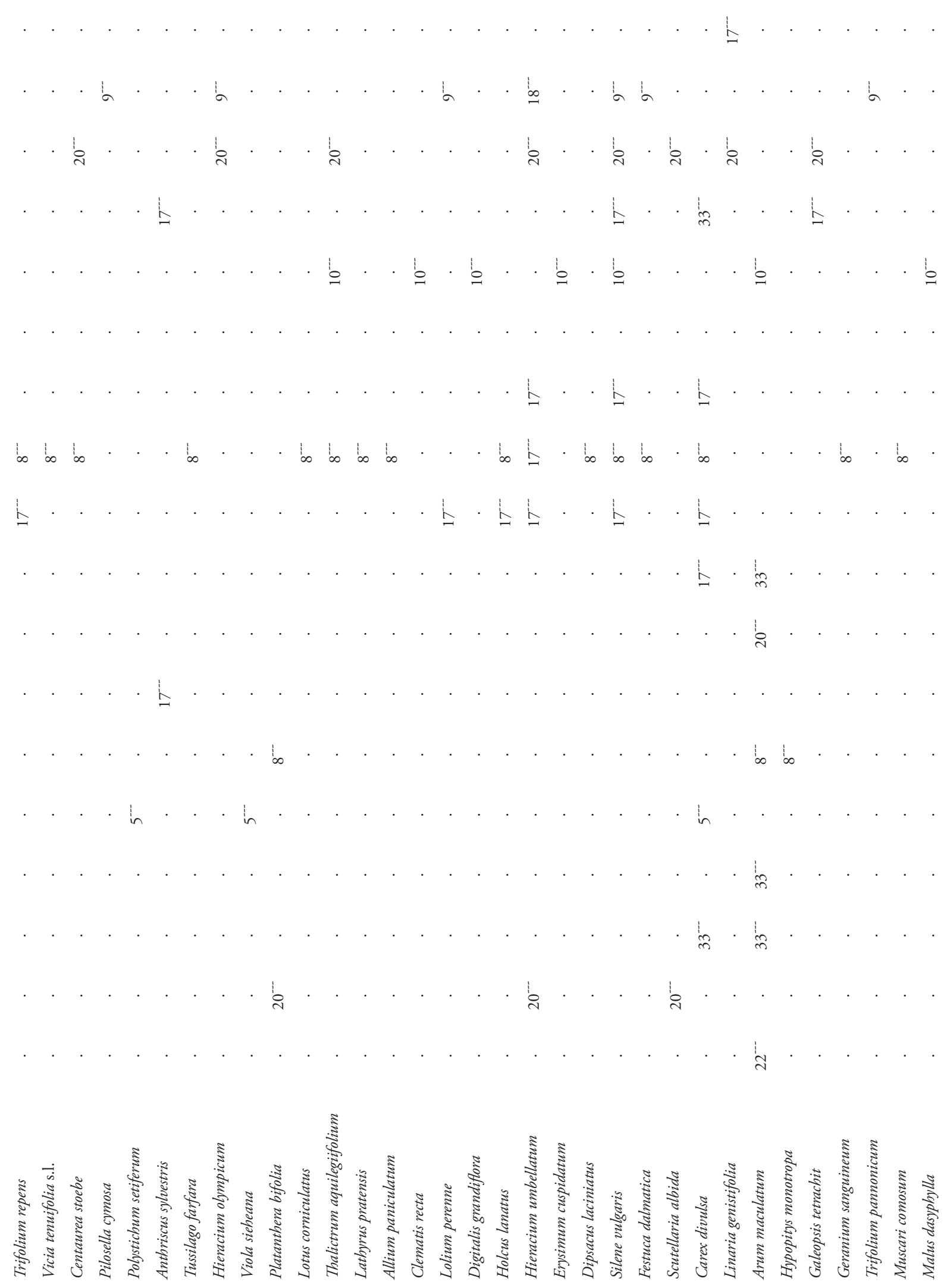




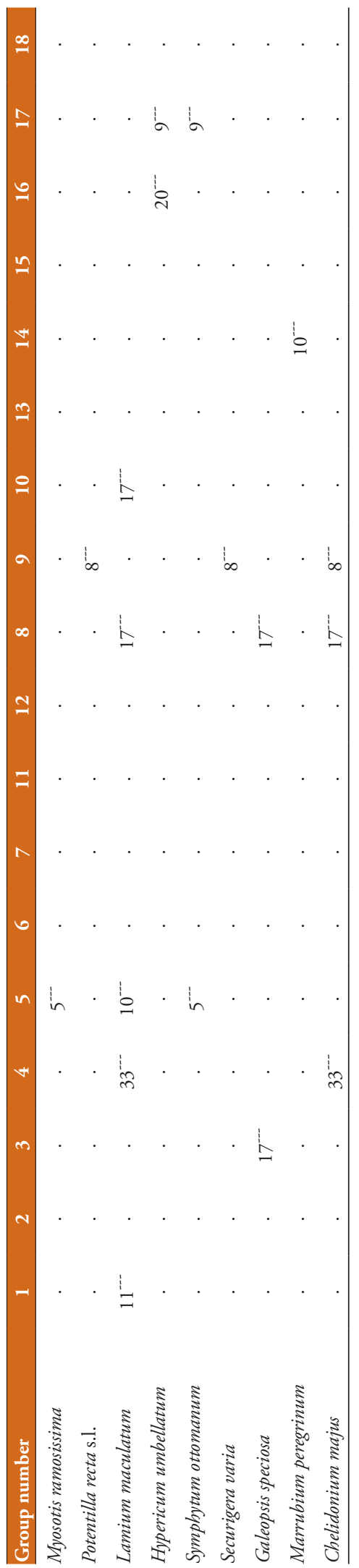

